\title{
Exploring the Relationship of Rush Hour Period and Fatal and Non-Fatal Crash Injuries in The U.S.: A Systematic Review and Meta-Analysis
}

\author{
Oluwaseun John Adeyemi ${ }^{\mathrm{a}}$, Ahmed Arif ${ }^{\mathrm{a}}$, Rajib Paul ${ }^{\mathrm{a}}$
}

a. Department of Public Health, University of North Carolina at Charlotte, North Carolina, USA, 28223

Corresponding Author

Oluwaseun John Adeyemi

Department of Public Health Sciences,

University of North Carolina at Charlotte,

North Carolina, 28223

USA

oadeyemi@uncc.edu 
medRxiv preprint doi: https://doi.org/10.1101/2021.08.03.21261572; this version posted August 5, 2021. The copyright holder for this preprint

(which was not certified by peer review) is the author/funder, who has granted medRxiv a license to display the preprint in perpetuity.

All rights reserved. No reuse allowed without permission.

\title{
Exploring the Relationship of Rush Hour Period and Fatal and Non-Fatal Crash Injuries: A Systematic Review and Meta-Analysis
}

\begin{abstract}
Road crashes are preventable causes of morbidity and mortality. In the U.S., substantial crashes occur during the rush hour period. The rush hour represents the period of the day during which the density of humans and vehicles in the road environment is highest. In the U.S., the rush hour period is bi-modal, occurring in the morning and the afternoon, at times that vary by state and urban-rural status. This systematic review and meta-analysis aimed to evaluate the association between the rush hour period and fatal and non-fatal crash injuries. Selected articles were limited to peer-reviewed full-text articles that measured crash injury as an outcome and rush hour as either a predictor, covariate, stratification, or a control variable. A total of 13 articles were identified for systematic review and seven articles were included in the meta-analysis. Across the selected studies, the rush-hour period signified the period of "peak traffic flow." During the rush hour period, aggressive driving behavior, truck driving, bicycle riding, and precipitation were associated with increased crash events or crash injuries. Across the seven studies included in the meta-analysis, the effective sample size was 220,471 . The rush-hour period was associated with a $41 \%$ increased risk of fatal crash injury (Pooled RR: 1.41; 95\% CI: 1.35 - 1.48). The morning and afternoon rush hour periods were associated with 40\% (Pooled RR: 1.40; 95\% CI: 1.13-1.67) and 27\% (Pooled RR:1.27; 95\% CI: 1.10-1.44) increased crash injury risk, respectively. The rush hour period, though less commonly studied as a predictor of fatal and non-fatal crash injuries, represents an important domain in need of crash injury prevention attention. The knowledge of the pattern of crash injuries, as it varies across countries, states, regions, and county can inform policy and intervention, in the presence of competing public health needs.
\end{abstract}


medRxiv preprint doi: https://doi.org/10.1101/2021.08.03.21261572; this version posted August 5, 2021. The copyright holder for this preprint (which was not certified by peer review) is the author/funder, who has granted medRxiv a license to display the preprint in perpetuity.

All rights reserved. No reuse allowed without permission.

Keywords: Rush hour; Peak Traffic; Fatal and non-fatal crash injury; Traffic Safety; MetaAnalysis; Research Synthesis; Public Health

Acknowledgment: The authors acknowledge Tasha Gills, MPH, and Jessica Hoyle, MMT for their editorial assistance.

Funding Source: This research did not receive any specific grant from funding agencies in the public, commercial, or not-for-profit sectors 


\section{Exploring the Relationship of Rush Hour Period and Fatal and Non-Fatal Crash Injuries in The U.S.: A Systematic Review and Meta-Analysis}

\section{Introduction}

Road crashes are significant yet preventable causes of morbidity and mortality. Approximately 1.25 million people die each year worldwide from road-related crash injuries (Center for Disease Control and Prevention, 2016). In the United States (U.S.), one person dies every 14 minutes from crash-related events (National Center for Statistics and Analysis, 2019b). While the U.S. recorded its first three-year successive decline in fatal crash counts in over a decade, annual fatal counts in 2018 exceeded 37,000 deaths (National Center for Statistics and Analysis, 2019a). Nevertheless, crash-related morbidity has not substantially declined despite declining fatal crash counts (National Highway Traffic Safety Administration, 2017).

Rush hour represents the period of the day during which the density of humans and vehicles in the road environment is highest. In the U.S., the rush hour period is bi-modal, occurring in the morning and the afternoon (Federal Highway Administration, 2017). The exact period varies across states and rural-urban categorization (Jaffe, 2014). A substantial proportion of fatal and non-fatal crash injuries happen during the rush hour period (HG.org, 2020). For example, in North Carolina, one out of every four crash events occurs during the afternoon rush hour period, and a lesser proportion occurs in the morning rush hour period (Tippett, 2014). Fatal road events account for about an annual average of 300 billion dollars in revenue (Tippett, 2014). The U.S. recorded a decline in road crash injuries death for the first time in 2017 (National Highway Traffic Safety Administration, 2017). While a decrease in fatalities is a measure of success (Injury Prevention Committee, 2017), the ultimate goal is to achieve a zero-traffic death (Ecola, Popper, Silberglitt, \& Fraade-Blanar, 2018). 
medRxiv preprint doi: https://doi.org/10.1101/2021.08.03.21261572; this version posted August 5, 2021. The copyright holder for this preprint (which was not certified by peer review) is the author/funder, who has granted medRxiv a license to display the preprint in perpetuity.

All rights reserved. No reuse allowed without permission.

The pattern of crash events during the rush hour or peak periods varies across countries. In the U.S., an urban Florida study reported higher average crash events during the rush hours compared to the non-rush hour period (Shi, Abdel-Aty, \& Lee, 2016). A 12-year pooled study using a national database in Spain reported that $51 \%$ of all crashes occur during the rush hour period, with injury severity higher in the peak period compared to the non-peak period (Llamazares, Useche, Montoro, \& Alonso, 2019). In contrast, a study conducted in an urban city in China reported lower average crash events during the rush hour period compared to the nonrush hour period (Yu, Wang, Yang, \& Abdel-Aty, 2016).

Several human and environmental factors are associated with crash events during the rush hour period. A study from an urban center in Florida reported that although the average volume of traffic and traffic volume per lane was less during the rush hour, vehicle occupancy, standard deviation of the vehicular speed, and the congestion index were higher during the rush hour period when compared to non-rush hour period (Shi et al., 2016). Also, six percent of children less than two years of age involved in fatal crash events were unrestrained (Huang, Liu, \& Pressley, 2019). Additionally, crash rates among teenage drivers in cities in Virginia were highest between 7 - 8 am and 2 - 6 pm (Vorona et al., 2011). Older drivers with functional impairment are more likely to avoid driving during rush hour compared to those without impairment (Ball et al., 1998).

Despite the vast literature on crash injury etiology, prevalence, and prevention, the rush hour or peak period literature is sparse. It is unknown to what extent fatal and non-fatal crash events are associated with the rush hour period. The presence of a significant relationship between the rush hour period and crash injury risks could present research areas on the unique environmental, behavioral, vehicular, and policy-related factors associated with rush hour-related 
fatal and non-fatal crash injuries. The rush-hour period may be used as a proxy for intervention aimed at preventing crash injuries if there is data-driven evidence that significant fatal and nonfatal crash injuries occur during this time period. Additionally, the knowledge of the crash injury risk associated with the rush hour may inform policy on lane expansion, utilization of high occupancy vehicle lanes, and road network and design. The research question guiding this literature search is: What is the association of the rush hour period with road crashes? This systematic review and meta-analysis aimed to evaluate the association between the rush hour period and fatal and non-fatal crash injuries.

\section{Methods}

\subsection{Criteria for selecting peer-reviewed articles}

The literature search was limited to peer-reviewed articles published between 2000 and 2020. Selected articles included full-text articles, written in English, with crash injury or event, measured in any form, serving as the outcome measure. Additionally, the rush hour must be measured as either a predictor, covariate, stratification, or control variable. Articles were restricted to the U.S. since traffic characteristics vary widely across countries. Experimental and qualitative studies and studies that do not measure the association between the rush hour period and crash injury or event were excluded.

\subsection{Search Criteria}

The synthesis of literature followed the Preferred Reporting Items for Systematic Reviews and Meta-Analyses (PRISMA) guidelines. Search strings were applied to the advanced search platform of the web pages of the popular databases. Specifically, the researcher searched PsycINFO, PubMed, Academic Search Complete, Cumulative Index of Nursing and Allied 
medRxiv preprint doi: https://doi.org/10.1101/2021.08.03.21261572; this version posted August 5, 2021. The copyright holder for this preprint

(which was not certified by peer review) is the author/funder, who has granted medRxiv a license to display the preprint in perpetuity.

All rights reserved. No reuse allowed without permission.

Health Literature (CINAHL), Web of Science, Scopus, and Transportation Research

International Documentation (TRID). A decision on search adequacy was made when no new item emerged from the databases.

The keywords in all the searches were ((("rush hour") OR ("peak traffic") AND (("road accident") OR ("road injury") OR ("road collision") OR ("road crash") OR ("traffic accident") OR ("traffic injury") OR ("traffic collision") OR ("traffic crash") OR ("highway accident") OR ("highway injury") OR ("highway crash") OR (“crash”) OR ("crash injury"))). This search string was applied to the PubMed database and fragmented as multiple searches for all the other databases. Essentially, the multiple searches performed on the other databases used the format "rush-hour" OR "peak traffic" AND the different iterations of "crash injury" stated above. While searching each database, inverted commas, or square or round brackets were applied as appropriate to the database.

Across all the databases, the searches were limited to the inclusion criteria (English, peerreviewed, 2000 - 2021). The selected articles were imported into an EndNote library. Duplicate articles were removed, and the abstracts were screened for the inclusion and exclusion criteria. Further screening was performed by reading the full texts (Figure 1).

\subsection{Data selection}

A total of 583 hits were generated after the search across the six databases. After excluding 329 duplicate articles, 254 abstracts and titles were screened. Based on the information contained in the title and abstract, 140 non-U.S. articles were excluded and an additional 36 articles were excluded for not meeting the inclusion criteria. After reading through the remaining 
medRxiv preprint doi: https://doi.org/10.1101/2021.08.03.21261572; this version posted August 5, 2021. The copyright holder for this preprint (which was not certified by peer review) is the author/funder, who has granted medRxiv a license to display the preprint in perpetuity.

All rights reserved. No reuse allowed without permission.

78 articles, 65 articles were excluded for not meeting the inclusion and exclusion criteria. A total of 13 articles were selected for synthesis. 
medRxiv preprint doi: https://doi.org/10.1101/2021.08.03.21261572; this version posted August 5, 2021. The copyright holder for this preprint (which was not certified by peer review) is the author/funder, who has granted medRxiv a license to display the preprint in perpetuity.

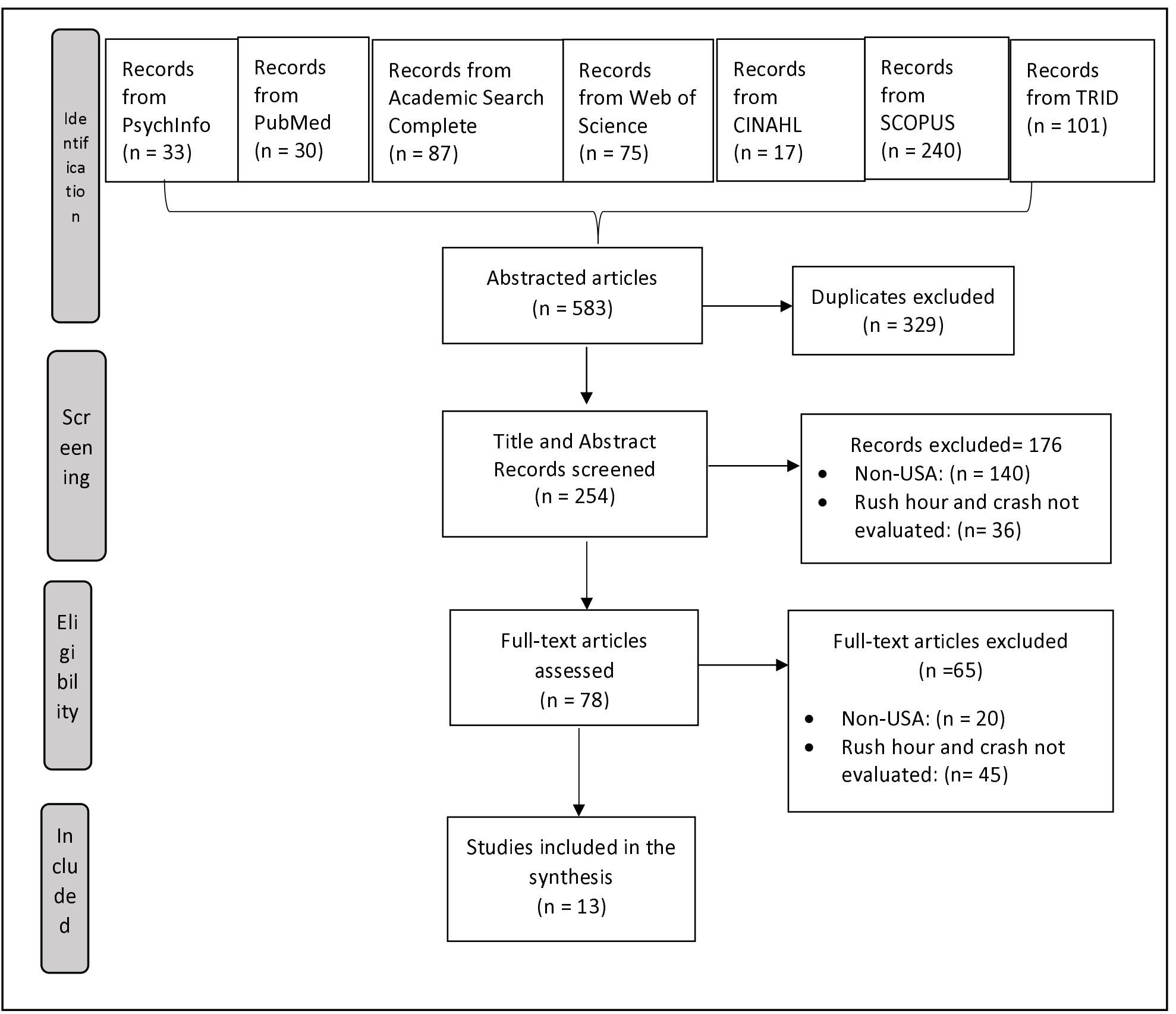

Figure 1. Preferred Reporting Items for Systematic Reviews and Meta-Analyses (PRISMA) flow chart showing the article selection steps for the systematic review 
medRxiv preprint doi: https://doi.org/10.1101/2021.08.03.21261572; this version posted August 5, 2021. The copyright holder for this preprint

(which was not certified by peer review) is the author/funder, who has granted medRxiv a license to display the preprint in perpetuity.

All rights reserved. No reuse allowed without permission.

\subsection{Methodological information and analysis}

The information gathered from the studies included the study design, data source, study population, study location, sample size, the stated or implied analytical framework, and how the rush hour and crash injury or event were defined. The coding scheme was designed to capture the inferential statistics used, and the odds or risks of crash injury or event associated with the rush hour period were documented.

The data reporting methods across the papers were streamlined for readability and consistency. The confidence intervals of coefficients or odds ratio were reported in preference to standard errors. For papers that reported only the coefficients and standard errors, the confidence intervals were computed using the formula: $C I=X \pm 1.96 S E$ where CI represents the lower and upper confidence intervals, $\mathrm{X}$ represents the coefficient, and SE represents the standard error. Logit coefficients were converted to odds ratio using the formula: $O R=e^{X}$ where OR represents the odds ratio, e represents the exponential function, and X represents the coefficient.

\subsection{Quality assessment}

Methodological quality assessment was performed using the Downs and Black checklist (Downs \& Black, 1998). The checklist is a 27-item list that captures the reporting, external, and internal validity measures of the study and the power of the study. The Downs and Black checklist has high reliability and validity values (Downs \& Black, 1998). The maximum score is 25 for non-randomized studies and 28 for randomized studies. Similar to previous studies, scores of 26 and higher were determined as excellent, 20 - 25 as good, 15 to 19 as fair, and 14 and lower as poor (Hooper, Jutai, Strong, \& Russell-Minda, 2008).

\subsection{Meta-Analysis}


A subset of the selected papers with reported odds, risks, or estimates of crash injury associated with the rush hour period was meta-analyzed. While some studies reported a single estimate for crash events during specified rush hour period, other provided estimates for each hour. Studies that did not report the odds ratio or coefficients and the associated confidence intervals were excluded. The effect sizes were computed for all selected studies. Subgroup analysis was performed by assessing the differences in the effect sizes in the morning and afternoon rush hour periods, and by fatal and non-fatal crash injuries. A meta-regression analysis was performed using the rush hour periods as predictors.

Since the data on crash injury or events were drawn from heterogeneous sources, a random effect was used in measuring the effect size of rush hour. Essentially, the random effect is stated thus: $T_{i}=\theta_{i}+\epsilon_{i}=\mu+e_{i}+\epsilon_{i}$, where $T_{i}$ represents the observed effect, $\theta_{i}$ represents the true effect, which is a sum of the mean $(\mu)$ and the within-study error $\left(e_{i}\right)$, and $\epsilon_{i}$ represents the between study error (Borenstein, Hedges, Higgins, \& Rothstein, 2010). For each study, weights were applied. Weights $\left(W_{i}^{*}\right)$ were calculated using the inverse variance $\left(v_{i}^{*}\right)$, a nuanced measure of the sample size, using the formula: $W_{i}^{*}=\frac{1}{v_{i}^{*}}$. The weighted mean $(T)$, therefore, represents the sum of the products of effect size $\left(T_{i}\right)$ and the weights $\left(W_{i}^{*}\right)$ divided by the sum of the weights $\left(W_{i}^{*}\right): T=\frac{\sum_{i=1}^{k} W_{i}^{*} T_{i}}{\sum_{i=1}^{k} W_{i}^{*}}$ (Borenstein et al., 2010).

Risk ratios were used in the meta-analysis to measure the effect size since most of the selected articles reported the odds and risk ratios of crash injury. The pooled risk ratio (RR) was assessed using the Mantel-Haenszel method using the formula: $\mathrm{RR}=\frac{\sum_{i=1}^{k} \frac{b_{i}+d_{i}}{n_{i}}}{\sum_{i=1}^{k} \frac{a_{i}+c_{i}}{n_{i}}}$, where a, b, c, and d represent exposed cases, non-exposed cases, exposed non-cases, non-exposed non-cases, 
respectively, and $\mathrm{n}$ is the sum of a, b, c, and d (Schmidt \& Kohlmann, 2008). Standard errors

(SE) were estimated using the formula: $\mathrm{SE}(\ln (\mathrm{RR}))=\sqrt{\frac{1}{a}+\frac{1}{c}-\frac{1}{a+b}-\frac{1}{c+d}}$ and the $95 \%$ confidence intervals were estimated from the standard errors using the formula: $95 \% \mathrm{CI}=\exp$ $(\ln (\mathrm{RR}) \pm 1.96 \times \mathrm{SE}(\ln (\mathrm{RR})))($ Schmidt \& Kohlmann, 2008)

Coefficient values, calculated using the risk estimates' natural log transformation, were used to assess publication bias. Test of heterogeneity $\left(\mathrm{I}^{2}\right)$, which reports the variability in the result, were reported. $\mathrm{I}^{2}$ represents the percentage of error due to between-study variations. Values of less than $25 \%$ indicate excellent, while values between 25 and $50 \%$ represent moderate heterogeneity (Higgins, Thompson, Deeks, \& Altman, 2003). Values above 50\% suggest some degree of homogeneity in the studies (Higgins et al., 2003). Funnel plots, trim and fill analysis, and Egger's regression test was used to assess publication bias. With the funnel plot, the symmetrical location of the studies around the population effect size suggests no bias (Peters, Sutton, Jones, Abrams, \& Rushton, 2008). The Egger test is a quantitative measure of the publication bias, with a p-value less than 0.05 suggestive of publication bias (Lin \& Chu, 2018). Using the trim and fill analysis, studies were trimmed to make the effect size less affected by publication bias and studies are imputed to achieve symmetrical distribution of the studies (Shi \& Lin, 2019). Statistical analysis was performed using STATA version 16 (StataCorp, 2020). 


\section{Results}

\subsection{Study characteristics}

Of the 583 articles identified using the search criteria, 13 papers met the inclusion and exclusion criteria, and these studies were included in the synthesis. All the selected papers used retrospective designs. Secondary data sources used in the selected studies ranged widely from national census data such as the Fatality Analysis Reporting System (FARS) (Huang, Liu, \& Pressley, 2019; Stevens, Schreck, Saha, Bell, \& Kunkel, 2019) and the National Motor Vehicular Crash Causation Survey (NMVCCS) (Paleti, Eluru, \& Bhat, 2010) to state-level data (Call, Medina, \& Black, 2019; Cook, Knight, \& Olson, 2005; Das, Pande, Abdel-Aty, \& Santos, 2008; Duddu, Kukkapalli, \& Pulugurtha, 2019; Haleem \& Gan, 2013; Jang, Chung, Ragland, Chan, \& Transportation Research, 2008; Kim, Kim, Ulfarsson, \& Porrello, 2007; Lee, Dittberner, \& Sripathi, 2007) (Table 1). The purpose of the papers varied widely. While some papers assessed the natural and environmental determinants of crash events or injuries (Call et al., 2019; Das et al., 2008; Jang et al., 2008; Lee et al., 2007; Marquis \& Wang, 2015; Stevens et al., 2019), others assessed the association of risky driving behaviors and the occurrence of crash events or injuries (Cook et al., 2005; Duddu et al., 2019; Huang et al., 2019; Ma, Hao, Xiang, \& Yan, 2018; Paleti et al., 2010). The study population focused on either the individuals involved in the crash (Huang et al., 2019; Kim et al., 2007; Paleti et al., 2010) or crash events (Call et al., 2019; Cook et al., 2005; Das et al., 2008; Jang et al., 2008; Lee et al., 2007; Ma et al., 2018; Marquis \& Wang, 2015). Also, the sample sizes had a wide range - from approximately 1,000 (Marquis \& Wang, 2015) to over 620,000 (Cook et al., 2005). Using the Down and Black checklist, the qualities of the studies were low to average. 
Table 1: Characteristics of the papers selected for the systematic review

\begin{tabular}{|c|c|c|c|c|c|c|}
\hline Authors (Year) & Purpose & Study Design & Data Source & Study Population & $\begin{array}{l}\text { Sample } \\
\text { Size }\end{array}$ & $\begin{array}{l}\text { Quality } \\
\text { Scores* (/28) }\end{array}$ \\
\hline Call et al., (2019) & $\begin{array}{l}\text { Assessed how crashes related to } \\
\text { weather differed by severity, date } \\
\text { and time, driver, and other } \\
\text { environmental conditions }\end{array}$ & Retrospective & $\begin{array}{l}\text { 2012-2016 Utah } \\
\text { DOT }\end{array}$ & $\begin{array}{l}\text { Motor vehicular crash } \\
\text { events }\end{array}$ & 14,863 & 8 \\
\hline Cook et al., (2005) & $\begin{array}{l}\text { Determined the characteristics } \\
\text { and outcomes associated with } \\
\text { aggressive driving crashes } \\
\text { compared to DUI and non-DUI } \\
\text { non-aggressive crashes }\end{array}$ & Retrospective & $\begin{array}{l}\text { 1992-2003 Utah } \\
\text { DOT } \\
\text { 1996-2002 ED, } \\
\text { University of Utah } \\
\text { 1992-2002 DOH, } \\
\text { University of Utah }\end{array}$ & $\begin{array}{l}\text { Motor vehicular crash } \\
\text { events }\end{array}$ & 621,451 & 8 \\
\hline Das et al., (2008) & $\begin{array}{l}\text { Assessed the factors associated } \\
\text { with crashes and crash injury } \\
\text { severity related to intersections } \\
\text { on multilane arterial roads }\end{array}$ & Retrospective & $\begin{array}{l}2002-2005 \text { crash } \\
\text { data from Florida } \\
\text { DOT }\end{array}$ & $\begin{array}{l}\text { Motor vehicular crash } \\
\text { events }\end{array}$ & 1,575 & 12 \\
\hline Duddu et al., (2019) & $\begin{array}{l}\text { Assessed the factors associated } \\
\text { with crash injury severity among } \\
\text { teen drivers }\end{array}$ & Retrospective & $\begin{array}{l}2011-2013 \\
\text { Highway Safety } \\
\text { Information } \\
\text { System, N.C. }\end{array}$ & $\begin{array}{l}\text { Crashes among teen } \\
\text { drivers }(15-19 \text { years })\end{array}$ & 62,990 & 13 \\
\hline Haleem et al., (2013) & $\begin{array}{l}\text { Assessed the predictors of injury } \\
\text { severity on urban freeways }\end{array}$ & Retrospective & $\begin{array}{l}2001-2005 \text { crash } \\
\text { data from Florida } \\
\text { DOT }\end{array}$ & $\begin{array}{l}\text { Non-fatal crash injury } \\
\text { events }\end{array}$ & 56,727 & 13 \\
\hline Huang et al., (2019) & $\begin{array}{l}\text { Assessed the characteristics of } \\
\text { fatal crashes among children with } \\
\text { missing restraint documentation }\end{array}$ & Retrospective & $\begin{array}{l}2008-2015 \text { FARS } \\
\text { data from NHTSA }\end{array}$ & $\begin{array}{l}\text { Child crash injury } \\
\text { severity }\end{array}$ & 4,966 & 13 \\
\hline Jang et al., (2008) & $\begin{array}{l}\text { Compared crash events on } \\
\text { different traffic routes }\end{array}$ & Retrospective & $\begin{array}{l}1999-2003 \text { crash } \\
\text { data from } \\
\text { California DOT }\end{array}$ & $\begin{array}{l}\text { Motor vehicular crash } \\
\text { events }\end{array}$ & 6,748 & 8 \\
\hline Kim et al., (2007) & $\begin{array}{l}\text { Predicted the occurrence of } \\
\text { bicycle-motor crashes using } \\
\text { human, vehicular, land, }\end{array}$ & Retrospective & $\begin{array}{l}1997-2002 \text { N.C. } \\
\text { police-reported } \\
\text { data }\end{array}$ & $\begin{array}{l}\text { Single motorist and } \\
\text { bicyclist road crash }\end{array}$ & 2934 & 13 \\
\hline
\end{tabular}




\begin{tabular}{|c|c|c|c|c|c|c|}
\hline & $\begin{array}{l}\text { environmental, and temporal } \\
\text { characteristics }\end{array}$ & & & & & \\
\hline Lee et al. (2007) & $\begin{array}{l}\text { Assessed the factors associated } \\
\text { with lane-specific traffic safety }\end{array}$ & Retrospective & $\begin{array}{l}2002-2004 \\
\text { Washington DC } \\
\text { and Virginia } \\
\text { police crash } \\
\text { report }\end{array}$ & $\begin{array}{l}\text { Motor vehicular crash } \\
\text { events }\end{array}$ & 1,613 & 13 \\
\hline Ma et al., (2018) & $\begin{array}{l}\text { Assessed the factors associated } \\
\text { with crash injury severity among } \\
\text { drivers with and without } \\
\text { aggressive driving behaviors }\end{array}$ & Retrospective & $\begin{array}{l}2005-2014 \\
\text { Federal Railroad } \\
\text { Administration } \\
\text { database }\end{array}$ & $\begin{array}{l}\text { Highway-rail crash } \\
\text { events }\end{array}$ & 25,945 & 13 \\
\hline Marquis et al., (2015) & $\begin{array}{l}\text { Assessed the temporal effects of } \\
\text { truck crash events }\end{array}$ & Retrospective & $\begin{array}{l}2008-2011 \text { crash } \\
\text { data from New } \\
\text { York State DOT }\end{array}$ & $\begin{array}{l}\text { Motor vehicular crash } \\
\text { events }\end{array}$ & 1,086 & 13 \\
\hline Paleti et al., (2010) & $\begin{array}{l}\text { Assessed the relationship of } \\
\text { aggressive driving behavior and } \\
\text { road accident injury, and the } \\
\text { moderating effect of } \\
\text { environmental and temporal } \\
\text { characteristics }\end{array}$ & Retrospective & $\begin{array}{l}2005-2007 \\
\text { NMVCCS data }\end{array}$ & $\begin{array}{l}\text { Crash observations of } \\
\text { drivers }\end{array}$ & 2,315 & 14 \\
\hline Stevens et al., (2019) & $\begin{array}{l}\text { Assessed the association of } \\
\text { precipitation and precipitation } \\
\text { intensity on fatal road crashes } \\
\text { and how the association changes } \\
\text { across regions and the times of } \\
\text { the day }\end{array}$ & Retrospective & $\begin{array}{l}2006-2011 \text { FARS } \\
\text { data }\end{array}$ & Fatal crash events & 125,012 & 13 \\
\hline
\end{tabular}

DOT: Department of Transportation; ED: Emergency Department; DoH: Department of Health; NC: North Carolina; DUI: Driving Under the Influence of alcohol and drugs; CAS: Crash Analysis System; FARS: Fatality Analysis Reporting System; NHTSA: National Highway Traffic Safety Administration; NMVCCS: National Motor Vehicular Crash Causation Survey; *Quality scores assessed using the Downs and Black checklist 


\begin{tabular}{|c|c|c|c|c|c|c|}
\hline \multirow[t]{2}{*}{ Authors (Year) } & \multirow[t]{2}{*}{$\begin{array}{l}\text { Conceptual definition of } \\
\text { rush hour }\end{array}$} & \multicolumn{2}{|c|}{ Reference time } & \multirow[t]{2}{*}{ State Location } & \multirow[t]{2}{*}{ Usage } & \multirow[t]{2}{*}{ Statistical Measure } \\
\hline & & AM & PM & & & \\
\hline Call et al., (2019) & Time of peak traffic & $7-9$ & $5-7$ & Utah & Descriptive & Proportion \\
\hline Cook et al., (2005) & Time of peak traffic & $7-8$ & $4-6$ & Utah & Descriptive & Proportion \\
\hline Das et al., (2008) & Time of peak traffic & $7-9: 30$ & $4-7$ & Florida & Predictor & $\begin{array}{l}\text { Bivariate Probit } \\
\text { Ordinal Probit }\end{array}$ \\
\hline Duddu et al., (2019) & Time of peak traffic & $6-9$ & $3-6$ & North Carolina & Predictor & $\begin{array}{l}\text { Partially Proportional } \\
\text { Ordinal Logistic }\end{array}$ \\
\hline Haleem et al., (2013) & Time of peak traffic & $7-11$ & $3-7$ & Florida & Predictor & $\begin{array}{l}\text { Mixed Logit } \\
\text { Binary Logit }\end{array}$ \\
\hline Huang et al., (2019) & Time of peak traffic & $7-9: 30$ & $3: 30-6$ & All U.S. States & Predictor & Logistic Regression \\
\hline Jang et al., (2008) & Time of peak traffic & $5-9$ & $3-7$ & California & $\begin{array}{l}\text { Stratified } \\
\text { outcome } \\
\text { measure }\end{array}$ & Proportion \\
\hline Kim et al., (2007) & Time of peak traffic & $6-10$ & $3-6$ & North Carolina & Predictor & Multinomial Logit \\
\hline Lee et al. (2007) & $\begin{array}{l}\text { The period when the road } \\
\text { shoulders are opened for } \\
\text { traffic flow }\end{array}$ & $5: 30-9: 30$ & $3-7$ & $\begin{array}{l}\text { Washington DC; } \\
\text { Virginia }\end{array}$ & Predictor & $\begin{array}{l}\text { Negative Binomial } \\
\text { Regression }\end{array}$ \\
\hline Ma et al., (2018) & Time of peak traffic & $6-9$ & $4-6$ & All U.S. States & Predictor & Mixed Logit \\
\hline Marquis et al., (2015) & Time of peak traffic & $6-10$ & $3-7$ & New York & $\begin{array}{l}\text { Stratifying } \\
\text { variable }\end{array}$ & Proportion \\
\hline Paleti et al., (2010) & Time of peak traffic & $6-9$ & $3-7$ & Texas & $\begin{array}{l}\text { Interaction } \\
\text { variable }\end{array}$ & Ordinal logistic \\
\hline Stevens et al., (2019) & $\begin{array}{l}\text { Period with the highest } \\
\text { crash event in the day }\end{array}$ & $6-9 *$ & $3-6^{*}$ & All U.S. States & Predictor & Relative Risk \\
\hline
\end{tabular}

Table 2: Rush hour definitions and statistical conceptualization

*Not stated but information obtained from the National Highway Traffic Safety Administration publication 
medRxiv preprint doi: https://doi.org/10.1101/2021.08.03.21261572; this version posted August 5, 2021. The copyright holder for this preprint (which was not certified by peer review) is the author/funder, who has granted medRxiv a license to display the preprint in perpetuity.

\subsection{Definition of the Rush Hour Period}

Across the selected studies, the rush hour period was referred to as the period with "peak traffic volume" (Call et al., 2019; Cook et al., 2005; Das et al., 2008; Duddu et al., 2019; Haleem \& Gan, 2013; Huang et al., 2019; Jang et al., 2008; Kim et al., 2007; Ma et al., 2018; Marquis \& Wang, 2015; Paleti et al., 2010) or the period with the highest road crash events (Stevens et al., 2019) (Table 2). The rush-hour period defined the time during which certain road processes were activated such as the period when the road shoulders are opened to accommodate increased traffic flow (Lee et al., 2007). The rush-hour period was not defined uniformly across the studies. The morning rush hour period started as early as 5 or 5:30 am in densely populated regions like Washington DC and Virginia (Lee et al., 2007) or states with a large population size like California (Jang et al., 2008). Additionally, studies conducted in densely populated areas like New York and Florida reported that the morning rush hour period ended at either 10 or 11 am (Haleem \& Gan, 2013; Marquis \& Wang, 2015). The median morning rush hour period starts at 6 am and ends at 9 am. The duration of the morning rush hour period hours was as short as one hour (Call et al., 2019) and as long as four hours (Haleem \& Gan, 2013; Jang et al., 2008; Kim et al., 2007; Marquis \& Wang, 2015). Similarly, the duration of the afternoon rush hour period was as short as two hours (Call et al., 2019; Cook et al., 2005; Ma et al., 2018) and as long as four hours (Haleem \& Gan, 2013; Jang et al., 2008; Lee et al., 2007; Paleti et al., 2010). Across the studies, the median afternoon rush hour period started at $3 \mathrm{pm}$ and ended at $7 \mathrm{pm}$. Among the selected studies, rush hour served different roles in research. Some studies used the rush hour period as a predictor variable (Das et al., 2008; Duddu et al., 2019; Haleem \& Gan, 2013; Huang et al., 2019; Kim et al., 2007; Lee et al., 2007; Ma et al., 2018; Stevens et al., 2019), as an 
medRxiv preprint doi: https://doi.org/10.1101/2021.08.03.21261572; this version posted August 5, 2021. The copyright holder for this preprint (which was not certified by peer review) is the author/funder, who has granted medRxiv a license to display the preprint in perpetuity.

All rights reserved. No reuse allowed without permission.

interaction or stratification variable (Marquis \& Wang, 2015; Paleti et al., 2010), or only for descriptive purposes (Call et al., 2019; Cook et al., 2005).

\subsection{Road Crash Definition}

Crash, as an outcome, was measured as either crash event (Call et al., 2019; Cook et al., 2005; Jang et al., 2008; Lee et al., 2007; Marquis \& Wang, 2015) or crash injury (Das et al., 2008; Duddu et al., 2019; Haleem \& Gan, 2013; Huang et al., 2019; Kim et al., 2007; Ma et al., 2018; Paleti et al., 2010; Stevens et al., 2019) across the selected studies (Table 3). Crash events were defined numerically as counts of crashes (Call et al., 2019; Cook et al., 2005; Jang et al., 2008; Lee et al., 2007; Marquis \& Wang, 2015) or categorically as the occurrence of a crash event (Das et al., 2008). Crash injuries were defined as either binary or as an ordinal variable. Binary definition of crash injury was either defined as fatal or non-fatal or severe or non-severe nonfatal injury (Haleem \& Gan, 2013). Ordinal definition of crash injury used either a threepoint or five-point scale (Das et al., 2008; Duddu et al., 2019; Huang et al., 2019; Kim et al., 2007; Ma et al., 2018; Paleti et al., 2010). The three-point scale was defined as killed/fatal, injured, and property damage only/no injury (Duddu et al., 2019; Huang et al., 2019; Ma et al., 2018) while the five-point scale was defined as fatal, incapacitating injury, non-incapacitating injury, possible injury, and no injury/property damage only (Das et al., 2008; Kim et al., 2007; Paleti et al., 2010). Across the selected studies, the analytical approaches involved the use of proportions, bivariate logit/ logistic regression, or ordinal probit, logit, or logistic regression models, multinomial logit regression model, mixed logit models, and negative binomial regression models (Table 2).

A substantial proportion of crash events occur during the rush hour period (Jang et al., 2008; Marquis \& Wang, 2015). There were conflicting results on the relationship of the rush 
hour study was crash events or crash injury. A few studies reported that the rush hour period was significantly associated with fatal or severe injury severity (Duddu et al., 2019; Huang et al., 2019; Ma et al., 2018) while others reported that the rush hour was associated with reduced odds of crash injury severity (Haleem \& Gan, 2013), reduced injury rates (Das et al., 2008), or reduced fatal injuries (Huang et al., 2019).

Across the selected studies, individual, vehicular, and environmental determinants of crash injury or events were assessed. Within the domain of the individual determinants of crash injury, the selected studies reported that the rush hour period was a trigger for aggressive driving behavior, with such behaviors more in the morning than in the afternoon rush hour period (Paleti et al., 2010). Aggressive driving behavior-related crashes were more during the rush hour period (Cook et al., 2005) compared to other times of the day.

Bicycle riding and truck driving were the vehicle determinants that emerged from the selected studies. Bicycle riding during the morning rush hour period was associated with an increased risk of fatal injury (Kim et al., 2007) while truck-related crash events were more in the morning rush hour period compared to the afternoon rush hour period (Marquis \& Wang, 2015). Within the domain of the built and natural road environment, the rush hour period was associated with increased intersection-related crash rates (Das et al., 2008). Also, adverse weather-related crashes were more during the rush hour period (Call et al., 2019) and rates of precipitationrelated fatal injury were significantly elevated during the morning and afternoon rush hour periods (Stevens et al., 2019)). The presence of shoulder travel lane, activated during the rush hour period, was not associated with significantly increased or reduced rates of fatal crash injuries (Lee et al., 2007) 
Table 3: Summary of the how road crash was defined and measured, as well as the rush hour-related analytical framework and summary findings in the selected studies.

\begin{tabular}{|c|c|c|c|c|}
\hline Authors (Year) & Outcome & Definition of outcome & Analytical framework & Relevant summary of findings \\
\hline Call et al., (2019) & Crash event & $\begin{array}{l}\text { Crash counts related } \\
\text { to adverse weather }\end{array}$ & $\begin{array}{l}\text { Quantify the proportion of } \\
\text { weather-related road crashes } \\
\text { during the rush hour period }\end{array}$ & $\begin{array}{l}\text { Crashes associated with adverse } \\
\text { weather were most numerous } \\
\text { around (not during) the rush hour } \\
\text { period }\end{array}$ \\
\hline Cook et al., (2005) & Crash event & $\begin{array}{l}\text { Crash counts at all } \\
\text { times of the day }\end{array}$ & $\begin{array}{l}\text { Quantify the proportion of } \\
\text { aggressive-related, DUI-related, } \\
\text { and other factors-related } \\
\text { crashes during the rush hour }\end{array}$ & $\begin{array}{l}\text { Crashes associated with } \\
\text { aggression and other factors are } \\
\text { highest during the morning and } \\
\text { afternoon rush hour periods. }\end{array}$ \\
\hline Das et al., (2008) & $\begin{array}{l}\text { Crash event } \\
\text { Crash injury }\end{array}$ & $\begin{array}{l}\text { Binary: Crashes } \\
\text { located from a } \\
\text { specified distance to } \\
\text { the intersection or not } \\
\text { Ordinal: Crash injury- } \\
\text { incapacitated and } \\
\text { fatal injuries, non- } \\
\text { incapacitating injuries, } \\
\text { possible injuries }\end{array}$ & $\begin{array}{l}\text { Estimate the association of } \\
\text { crash event/crash injury and } \\
\text { morning and afternoon peak } \\
\text { traffic period (weekday), } \\
\text { compared to the off-peak } \\
\text { period }\end{array}$ & $\begin{array}{l}\text { The rush-hour period as compared } \\
\text { to off-peak traffic was not } \\
\text { significantly associated with crash } \\
\text { events. The afternoon rush hour } \\
\text { period as compared to off-peak } \\
\text { traffic is associated with a reduced } \\
\text { injury rate. }\end{array}$ \\
\hline Duddu et al., (2019) & Crash injury & $\begin{array}{l}\text { Ordinal: Property } \\
\text { damage only; } \\
\text { Moderate injury, } \\
\text { Severe injury }\end{array}$ & $\begin{array}{l}\text { Estimate how the morning and } \\
\text { afternoon peak period as } \\
\text { compared to } 12 \text { AM to } 3 \text { AM } \\
\text { associates with crash injury } \\
\text { severity }\end{array}$ & $\begin{array}{l}\text { The morning and afternoon rush } \\
\text { hour period were significantly } \\
\text { associated with the severe injury } \\
\text { severity }\end{array}$ \\
\hline Haleem et al., (2013) & Non-fatal crash injury & $\begin{array}{l}\text { Binary: Severe vs. } \\
\text { Non-severe crash } \\
\text { injury }\end{array}$ & $\begin{array}{l}\text { Estimate how the number of } \\
\text { crashes during the rush hour } \\
\text { associate with severe crash } \\
\text { injury }\end{array}$ & $\begin{array}{l}\text { The morning and afternoon rush } \\
\text { hour crash counts were associated } \\
\text { with reduced odds of severe injury } \\
\text { as compared to the off-peak } \\
\text { period. }\end{array}$ \\
\hline Huang et al., (2019) & Child injury severity & $\begin{array}{l}\text { Ordinal: Not injured, } \\
\text { Injured, Died }\end{array}$ & $\begin{array}{l}\text { Assess the association of the } \\
\text { rush hour period and fatal }\end{array}$ & $\begin{array}{l}\text { The rush-hour period was not } \\
\text { significantly associated with fatal }\end{array}$ \\
\hline
\end{tabular}




\begin{tabular}{|c|c|c|c|c|}
\hline & & & $\begin{array}{l}\text { crash injury among } \\
\text { unrestrained children }\end{array}$ & $\begin{array}{l}\text { crash injuries among unrestrained } \\
\text { children }\end{array}$ \\
\hline Jang et al., (2008) & Crash events & $\begin{array}{l}\text { Crash events during } \\
\text { the rush hour period } \\
\text { on specific lanes }\end{array}$ & $\begin{array}{l}\text { Estimate the proportion of } \\
\text { crash events during the rush } \\
\text { hour period }\end{array}$ & $\begin{array}{l}\text { A substantial proportion of } \\
\text { crashes occur during the rush hour } \\
\text { period }\end{array}$ \\
\hline Kim et al., (2007) & Crash injury & $\begin{array}{l}\text { Ordinal categories: } \\
\text { fatal injury } \\
\text { Incapacitating injury } \\
\text { Non-incapacitating } \\
\text { injury } \\
\text { Possible / No injury }\end{array}$ & $\begin{array}{l}\text { Estimate the odds of fatal, } \\
\text { incapacitating, and non- } \\
\text { incapacitating injury during the } \\
\text { rush hour period }\end{array}$ & $\begin{array}{l}\text { Riding bicycles during the morning } \\
\text { peak traffic increases the risk of } \\
\text { fatal injury }\end{array}$ \\
\hline Lee et al. (2007) & Crash events & $\begin{array}{l}\text { Daily number of crash } \\
\text { events on weekdays }\end{array}$ & $\begin{array}{l}\text { Estimate the association of } \\
\text { access of the shoulder travel } \\
\text { lane activity and crash events. }\end{array}$ & $\begin{array}{l}\text { The presence of shoulder travel } \\
\text { lane traffic activity, which } \\
\text { coincides with the rush hour } \\
\text { period), is not significantly } \\
\text { associated with increased crash } \\
\text { events }\end{array}$ \\
\hline Ma et al., (2018) & Crash injury severity & $\begin{array}{l}\text { Ordinal: Property } \\
\text { damage only, Injured, } \\
\text { Killed }\end{array}$ & $\begin{array}{l}\text { Estimate the association of } \\
\text { rush hour crashes and crash } \\
\text { injury severity among drivers } \\
\text { with aggressive and non- } \\
\text { aggressive driving behaviors }\end{array}$ & $\begin{array}{l}\text { Rush hour crashes were } \\
\text { associated with increased odds of } \\
\text { fatal events and injuries among } \\
\text { drivers with aggressive and non- } \\
\text { aggressive driving behavior. }\end{array}$ \\
\hline Marquis et al., (2015) & Crash events & $\begin{array}{l}\text { Truck and non-truck- } \\
\text { related crash counts }\end{array}$ & $\begin{array}{l}\text { Estimate the proportion of } \\
\text { truck and non-truck-related } \\
\text { crash counts during the } \\
\text { morning and afternoon peak } \\
\text { period }\end{array}$ & $\begin{array}{l}\text { A substantial proportion of truck- } \\
\text { related crash events occur during } \\
\text { the morning and afternoon rush } \\
\text { hour period }\end{array}$ \\
\hline Paleti et al., (2010) & Crash Injury severity & $\begin{array}{l}\text { Ordinal variable } \\
\text { No injury, possible } \\
\text { injury, non- } \\
\text { incapacitating injury, } \\
\text { incapacitating injury, } \\
\text { fatal injury }\end{array}$ & $\begin{array}{l}\text { Determine the relationship of } \\
\text { aggressive behavior to road } \\
\text { crash events }\end{array}$ & $\begin{array}{l}\text { The morning rush hour period } \\
\text { triggers aggressive driving } \\
\text { behavior and increases the risk of } \\
\text { road crashes. }\end{array}$ \\
\hline Stevens et al., (2019) & Fatal crash injury & Aggregated fatal & Evaluate the rate of the & Precipitation-related relative risk \\
\hline
\end{tabular}




$$
\text { counts }
$$$$
\text { precipitation-related fatal crash }
$$

$$
\text { event }
$$

peaks during the morning rush

hour period and remain

significantly elevated during the afternoon rush hour period. 
medRxiv preprint doi: https://doi.org/10.1101/2021.08.03.21261572; this version posted August 5, 2021. The copyright holder for this preprint

(which was not certified by peer review) is the author/funder, who has granted medRxiv a license to display the preprint in perpetuity.

All rights reserved. No reuse allowed without permission.

\subsection{Prevalence of Crash Injuries During the Rush Hour}

About $23 \%$ and $21 \%$ of truck crashes occur during the morning and afternoon rush hour periods (Marquis \& Wang, 2015) (Table 4). Also, about 9\% and 33\% of bicycle-related crashes occur during the morning and afternoon rush hour periods, respectively (Kim et al., 2007). Also, $6.5 \%$ and $8.5 \%$ of aggressive driving-related crash events occur during the morning and afternoon rush hour periods, respectively (Cook et al., 2005). The prevalence of crash events due to driving under the influence of alcohol or substance use (DUI) was $2 \%$ and $8.5 \%$ during the morning and afternoon rush hour periods, respectively (Cook et al., 2005). Across the selected studies, $14-16 \%$ and $7-11 \%$ of weather-related crashes occur during the morning and afternoon rush hour periods, respectively (Call et al., 2019).

\subsection{Rush Hour and Crash Injuries}

During the rush hour period, precipitation was significantly associated with increased fatal crash injury risk (Stevens et al., 2019) (Table 4). There was no statistical relationship between intersection-related severe and fatal crash injury and the morning rush hour traffic volume (Das et al., 2008). However, the afternoon rush hour traffic volume was associated with reduced odds of intersection-related fatal and severe injury severity (Das et al., 2008). The rushhour period was significantly associated with increased odds of severe injury among teen drivers (Duddu et al., 2019). Aggressive driving behavior was associated with increased odds of fatal crash injuries and non-fatal injuries during the rush hour period (Ma et al., 2018). Also, the rush hour period was associated with increased fatal injury among unrestrained children (Huang et al., 2019). 
Table 4: Summary of the relationships reported across the studies between rush hour period and road crash injuries

\begin{tabular}{|c|c|c|c|c|}
\hline \multirow[t]{2}{*}{ Authors (Year) } & \multirow[t]{2}{*}{ Rush hour period } & \multicolumn{3}{|c|}{ Outcome Measures } \\
\hline & & Injury Severity & Fatal Crash Injury & Crash Events \\
\hline \multirow[t]{9}{*}{ Call et al., (2019) } & Morning Rush hour & & & Weather-related crashes \\
\hline & $7-8 \mathrm{am}$ & & & $16 \%$ \\
\hline & $8-9$ am & & & $14 \%$ \\
\hline & $9-10 \mathrm{am}$ & & & $15.5 \%$ \\
\hline & Afternoon Rush hour: & & & Weather-related crashes \\
\hline & $3-4 p m$ & & & $8.5 \%$ \\
\hline & $4-5 p m$ & & & $7.5 \%$ \\
\hline & $5-6 p m$ & & & $8.5 \%$ \\
\hline & $6-7 \mathrm{pm}$ & & & $11.0 \%$ \\
\hline \multirow[t]{11}{*}{ Cook et al., (2005) } & Morning Rush Hour & & & \\
\hline & $7-8 \mathrm{am}$ & & & Aggressive driving $-6.5 \%$ \\
\hline & $7-8 \mathrm{am}$ & & & DUI $-2.0 \%$ \\
\hline & $7-8 \mathrm{am}$ & & & Others - 5.0\% \\
\hline & Afternoon Rush Hour & & & \\
\hline & $4-5 \mathrm{pm}$ & & & Aggressive driving $-8.5 \%$ \\
\hline & $4-5 p m$ & & & DUI $-8.5 \%$ \\
\hline & $4-5 \mathrm{pm}$ & & & Others $-4.5 \%$ \\
\hline & $5-6 p m$ & & & Aggressive driving - 9.5\% \\
\hline & $5-6 p m$ & & & DUI - 5.0\% \\
\hline & $5-6 p m$ & & & Others $-9.8 \%$ \\
\hline \multirow[t]{7}{*}{ Das et al., (2008) } & Morning Rush Hour & $\begin{array}{l}\text { Incapacitated/Fatal/Non- } \\
\text { Incapacitated Injury }\end{array}$ & & \\
\hline & & $D=0: 0.045(p=0.710)$ & & $D=0:-0.061(p=0.625)$ \\
\hline & & $D=50: 0.042(p=0.729)$ & & $D=50:-0.055(p=0.671)$ \\
\hline & & $D=100: 0.040(p=0.737)$ & & $D=100:-0.063(p=0.638)$ \\
\hline & & $D=150: 0.039(p=0.745)$ & & $D=150:-0.062(p=0.685)$ \\
\hline & & $D=200: 0.040(p=0.741)$ & & $D=200:-0.122(p=0.424)$ \\
\hline & Afternoon Rush Hour & $\begin{array}{l}\text { Incapacitated/Fatal/Non- } \\
\text { Incapacitated Injury }\end{array}$ & & \\
\hline
\end{tabular}




\begin{tabular}{|c|c|c|c|c|}
\hline & & $\begin{array}{l}D=0:-0.216(p=0.017) \\
D=50:-0.214(p=0.019) \\
D=100:-0.215(p=0.018) \\
D=150:-0.214(p=0.018) \\
D=200:-0.214(p=0.019)\end{array}$ & & $\begin{array}{l}D=0:-0.080(p=0.338) \\
D=50:-0.166(p=0.074) \\
D=100:-0.148(p=0.125) \\
D=150:-0.157(p=0.152) \\
D=200:-0.176(p=0.115)\end{array}$ \\
\hline \multirow[t]{2}{*}{ Duddu et al., (2019) } & Morning Rush Hour & $\begin{array}{l}\text { Teen Drivers: Severe Injury } \\
\text { 12.3\%; OR: } 1.16(p<0.05))\end{array}$ & & \\
\hline & Afternoon Rush Hour & $\begin{array}{l}\text { Teen Drivers: Severe Injury } \\
29.5 \% \text {; OR: } 1.16(p<0.05)\end{array}$ & & \\
\hline \multirow[t]{2}{*}{ Haleem et al., (2013) } & Morning Rush Hour & $\begin{array}{l}\text { Urban Freeways: Severe } \\
\text { Injury } \\
18.2 \% ; 0.98(0.88-1.09)\end{array}$ & & \\
\hline & Afternoon Rush Hour & $\begin{array}{l}\text { Urban Freeways: Severe } \\
\text { Injury } \\
26.4 \% ; 0.93(0.83-1.03)\end{array}$ & & \\
\hline Huang et al., (2019) & $\begin{array}{l}\text { Morning and } \\
\text { Afternoon Rush Hour }\end{array}$ & & & $\begin{array}{l}\text { Unrestrained child crash } \\
\text { event: } \\
\text { OR: } 0.85(0.65-1.10)\end{array}$ \\
\hline Jang et al., (2008) & $\begin{array}{l}\text { Morning and } \\
\text { Afternoon Rush Hour }\end{array}$ & & & Traffic volume: $28.6 \%$ \\
\hline \multirow[t]{2}{*}{ Kim et al., (2007) } & Morning Rush Hour & & $1.91(0.95-3.82) * * *$ & Bicycle crashes: $9.3 \%$ \\
\hline & Afternoon Rush Hour & & NR & Bicycle crashes: $33.0 \%$ \\
\hline Lee et al. (2007) & $\begin{array}{l}\text { Morning and } \\
\text { Afternoon Rush Hour }\end{array}$ & & & $\begin{array}{l}\text { All lanes: } * * * \\
\text { East: } 1.11(0.99-1.24) \\
\text { West: } 0.96(0.87-1.06) \\
\text { General Purpose lanes } \\
\text { East: } 1.11(0.97-1.27) \\
\text { West: } 0.95(0.84-1.06) \\
\text { Right shoulders } \\
\text { East: } 1.34(0.94-1.93) \\
\text { West: } 0.98(0.76-1.25) \\
\text { Inner lanes: } \\
\text { East: } 1.14(0.92-1.40) \\
\text { West: } 1.03(0.84-1.26)\end{array}$ \\
\hline
\end{tabular}




\begin{tabular}{|c|c|c|c|c|}
\hline \multirow[t]{5}{*}{ Ma et al., (2018) } & \multicolumn{4}{|l|}{ Morning and } \\
\hline & Afternoon Rush Hour & Aggressive driving: & Aggressive driving: & \\
\hline & & $14.03(8.48-23.21)$ & $10.19(3.73-27.84)$ & \\
\hline & & Appropriate driving: & Appropriate driving: & \\
\hline & & $7.03(2.05-24.07)$ & $4.85(2.34-10.07)$ & \\
\hline \multirow[t]{2}{*}{ Marquis et al., (2015) } & Morning Rush Hour & & & Truck crashes: $22.7 \%$ \\
\hline & Afternoon Rush Hour & & & Truck crashes: $20.5 \%$ \\
\hline \multirow[t]{3}{*}{ Paleti et al., (2010) } & Morning rush hour & & Aggressive driving: & \\
\hline & & & $1.48(0.99-2.20) * * *$ & \\
\hline & Afternoon rush hour & & NR & \\
\hline \multirow[t]{9}{*}{ Stevens et al., (2019) } & Morning rush hour & & Precipitation: & \\
\hline & 6-7 am & & $1.49(1.38-1.62)$ & \\
\hline & $7-8 \mathrm{am}$ & & $1.48(1.34-1.61)$ & \\
\hline & $8-9$ am & & $1.60(1.44-1.75)$ & \\
\hline & Afternoon rush hour & & Precipitation: & \\
\hline & 3-4 pm & & $1.40(1.35-1.50)$ & \\
\hline & 4-5 pm & & $1.35(1.24-1.44)$ & \\
\hline & $5-6 \mathrm{pm}$ & & $1.35(1.20-1.41)$ & \\
\hline & 6-7 pm & & $1.32(1.18-1.40)$ & \\
\hline
\end{tabular}

*Indirect effect reported; **logit value reported; $\mathrm{D}=$ Distance (in feet) from the intersection; $\mathrm{p}=\mathrm{p}$-value; *** Odds ratio and confidence interval

computed from logit coefficient and standard errors, respectively 
medRxiv preprint doi: https://doi.org/10.1101/2021.08.03.21261572; this version posted August 5, 2021. The copyright holder for this preprint (which was not certified by peer review) is the author/funder, who has granted medRxiv a license to display the preprint in perpetuity.

All rights reserved. No reuse allowed without permission.

\subsection{Summary of Meta-analysis}

A total of seven studies with reported risks, odds, or coefficients of fatal and non-fatal crash injury from the rush hour period were selected for the meta-analysis (Table 5). The effective sample size, excluding duplicated studies, was 220,471. The seven studies provided 24 point estimates for either or both morning and afternoon rush hour periods. Less than half of the selected studies reported separate crash injury estimates for the morning and afternoon rush hour period (Haleem \& Gan, 2013; Kim et al., 2007; Stevens et al., 2019). Stevens et al. (2019) reported crash risks for every hour during the rush hour period while Lee et al. (2007) reported estimates for different lanes during the rush hour period. Ma et al. (2018) reported the odds of severe injury due to aggressive and appropriate driving during the rush hour period.

\subsection{Meta-analysis: Rush Hour and Crash Event/Injury}

Across all the seven selected studies and 24 point estimates, the pooled risk for rush hour as a predictor of crash injury was 1.21 (95\% CI: $1.11-1.32)$ (Figure 2A). The test for heterogeneity was considerably high across all selected studies since some studies had multiple entries $\left(\mathrm{I}^{2}=89.02 \%\right)$. There was visual evidence of publication bias, with most of the selected studies asymmetrically located on one side the pooled effect size (Figure 2B). The Egger test was statistically significant $(\mathrm{p}<0.001)$, suggesting that there was statistical evidence of publication bias (Table 6). Using the Trim and Fill analysis, five studies were imputed (n=29) (Figure 2C). The effect size, after adjusting for publication bias, was 1.20 (95\% CI: $1.10-1.31)$, suggesting that the rush hour period was associated with a $20 \%$ increased risk of crash injury/event (Table $6)$. 


\begin{tabular}{|c|c|c|c|c|c|}
\hline Study & Sample Size* & Crash Injury & Period & Effect Size $(95 \% \mathrm{Cl})$ & \% Weight \\
\hline Haleem et al., 2013 & 56727 & Non-fatal & AM & $0.98(0.88-1.09)$ & 6.05 \\
\hline Haleem et al., 2013 & 56727 & Non-fatal & PM & $0.93(0.83-1.03)$ & 6.08 \\
\hline Huang et al., 2019 & 4966 & Fatal & ВОТН & $0.85(0.05-1.16)$ & 2.31 \\
\hline Kim et al., 2007 & 2934 & Fatal & AM & $1.91(0.95-3.82)$ & 0.5 \\
\hline Lee et al., 2007 & 559 & Crash & ВОTH & $1.11(0.99-1.24)$ & 5.9 \\
\hline Lee et al., 2007 & 643 & Crash & ВОтН & $0.96(0.87-1.06)$ & 6.12 \\
\hline Lee et al., 2007 & 175 & Crash & ВОTH & $1.14(0.92-1.4)$ & 4.82 \\
\hline Lee et al., 2007 & 128 & Crash & ВОтH & $1.03(0.84-1.26)$ & 5.12 \\
\hline Lee et al., 2007 & 379 & Crash & ВОTH & $1.11(0.97-1.27)$ & 5.69 \\
\hline Lee et al., 2007 & 507 & Crash & ВОтH & $0.95(0.84-1.06)$ & 6.01 \\
\hline Lee et al., 2007 & 90 & Crash & ВОTH & $1.34(0.94-1.93)$ & 2.66 \\
\hline Lee et al., 2007 & 91 & Crash & ВОтH & $0.98(0.76-1.25)$ & 4.77 \\
\hline Ma et al., 2018 & 11481 & Fatal & ВОтH & $14.03(8.48-23.21)$ & 0.02 \\
\hline Ma et al., 2018 & 11481 & Fatal & ВОТН & $7.03(2.05-24.07)$ & 0.01 \\
\hline Ma et al., 2018 & 14464 & Non-fatal & ВОтH & $4.85(2.34-10.07)$ & 0.07 \\
\hline Ma et al., 2018 & 14464 & Non-fatal & ВОTH & $10.19(3.73-27.84)$ & 0.01 \\
\hline Paleti et al., 2010 & 2315 & Fatal & ВОTH & $1.48(0.99-2.20)$ & 2.06 \\
\hline Stevens et al., 2019 & 125012 & Fatal & AM & $1.49(1.38-1.62)$ & 5.94 \\
\hline Stevens et al., 2019 & 125012 & Fatal & AM & $1.48(1.34-1.61)$ & 5.82 \\
\hline Stevens et al., 2019 & 125012 & Fatal & AM & $1.6(1.44-1.75)$ & 5.65 \\
\hline Stevens et al., 2019 & 125012 & Fatal & PM & $1.4(1.35-1.50)$ & 6.23 \\
\hline Stevens et al., 2019 & 125012 & Fatal & PM & $1.35(1.24-1.44)$ & 6.08 \\
\hline Stevens et al., 2019 & 125012 & Fatal & PM & $1.35(1.20-1.41)$ & 6.05 \\
\hline Stevens et al., 2019 & 125012 & Fatal & PM & $1.32(1.18-1.40)$ & 6.01 \\
\hline
\end{tabular}

Table 5: Summary of studies used in the meta-analysis

*Unique sample size $=220,471$ excluding the duplicated studies that reported morning and afternoon rush hour estimates 
medRxiv preprint doi: https://doi.org/10.1101/2021.08.03.21261572; this version posted August 5, 2021. The copyright holder for this preprint (which was not certified by peer review) is the author/funder, who has granted medRxiv a license to display the preprint in perpetuity. All rights reserved. No reuse allowed without permission.

Haleem et al.,(2013)

Haleem et al.,(2013)

Huang et al.,(2019)

Kim et al.,(2007)

Ma et al.,(2018)

Ma et al.,(2018)

Ma et al.,(2018)

Ma et al.,(2018)

Lee et al.,(2007)

Lee et al.,(2007)

Lee et al.,(2007)

Lee et al.,(2007)

Lee et al.,(2007)

Lee et al.,(2007)

Lee et al.,(2007)

Lee et al.,(2007)

Paleti et al.,(2010)

Stevens et al.,(2019)

Stevens et al.,(2019)

Stevens et al.,(2019)

Stevens et al.,(2019)

Stevens et al.,(2019)

Stevens et al.,(2019)

Stevens et al.,(2019)

with $95 \% \mathrm{Cl}$

(\%)

\section{Overall}

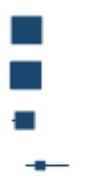

$0.98[0.88,1.09]$

0.93 [ $0.83,1.03$ ]

$0.85[0.05,1.16]$

$1.91[0.95,3.82]$

14.03 [ $8.48,23.21]$

7.03 [ 2.05, 24.07]

4.85 [ $2.34,10.07]$

10.19 [ $3.73,27.84]$

1.11 [ $0.99,1.24$ ]

$0.96[0.87,1.06$ ]

$1.14[0.92,1.40]$

$1.03[0.84,1.26]$

$1.11[0.97,1.27]$

$0.95[0.84,1.06]$

$1.34[0.94,1.93]$

$0.98[0.76,1.25]$

$1.48[0.99,2.20]$

$1.49[1.38,1.62]$

$1.48[1.34,1.61]$

$1.60[1.44,1.75]$

$1.40[1.35,1.50]$

$1.35[1.24,1.44]$

$1.35[1.20,1.41]$

$1.32[1.18,1.40]$

$1.21[1.11,1.32]$

Heterogeneity: $\mathrm{T}^{2}=0.04, \mathrm{I}^{2}=89.02 \%, \mathrm{H}^{2}=9.10$

Test of $\theta_{i}=\theta_{j}: Q(23)=232.56, p=0.00$

Test of $\theta=0: z=22.60, p=0.00$

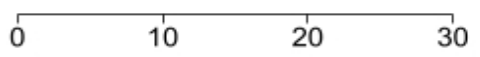

Random-effects REML model

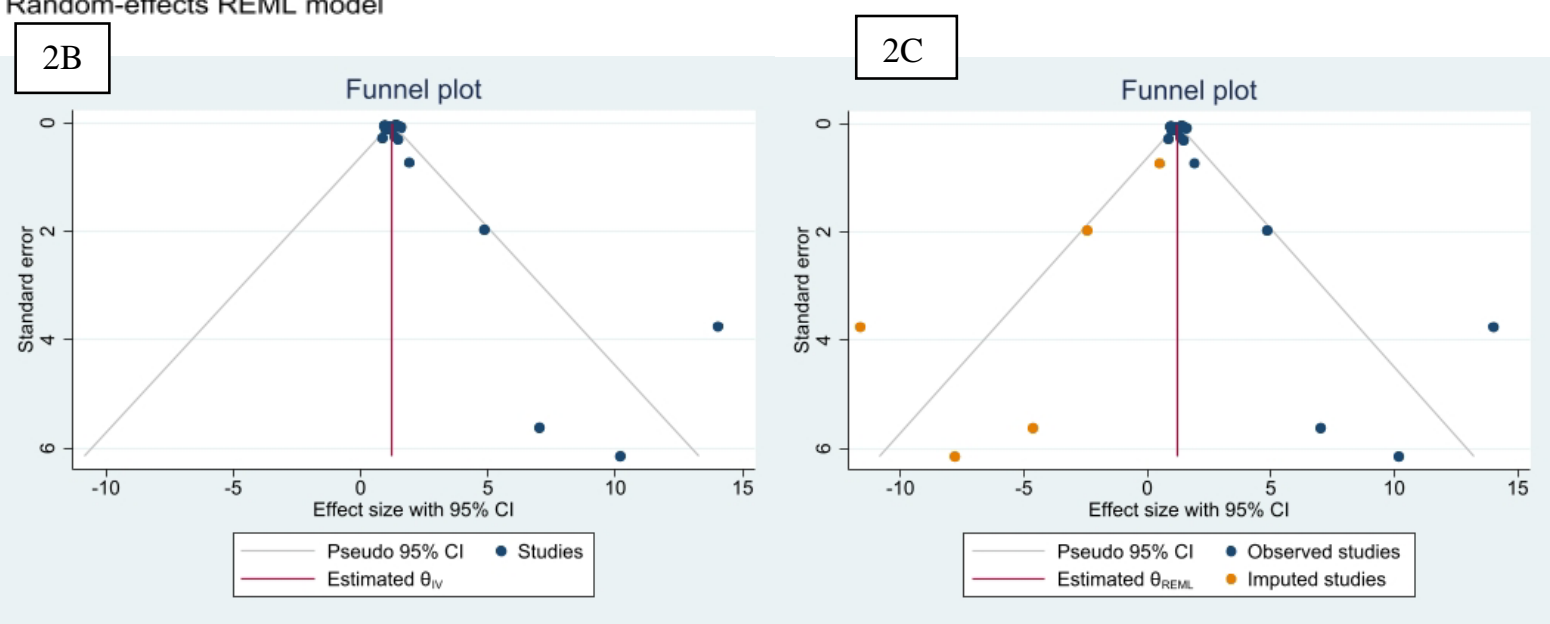

Figure 2: Forest plot (A), funnel plot (B), and Trim and Fill analysis plot (C) of the selected studies showing the effect size and publication bias and the adjustment for publication bias 
medRxiv preprint doi: https://doi.org/10.1101/2021.08.03.21261572; this version posted August 5, 2021. The copyright holder for this preprint (which was not certified by peer review) is the author/funder, who has granted medRxiv a license to display the preprint in perpetuity.

All rights reserved. No reuse allowed without permission.

Table 6: Summary of the Trim and Fill analysis showing the adjusted effect size and the Egger test evaluation of publication bias across the selected studies.

\begin{tabular}{lll}
\hline \multicolumn{2}{c}{ Trim and Fill Analysis } \\
\hline Studies & Theta & $95 \% \mathrm{Cl}$ \\
Observed $(\mathrm{n}=24)$ & 1.21 & $1.11-1.32$ \\
Observed + Imputed (29) & 1.20 & $1.10-1.31$ \\
& & \\
& & Regression-based Egger test for small-study effects \\
\hline Beta (Standard Error) & Z-value & 0.001 \\
$1.44(0.42)$ & 3.43 & \\
\hline
\end{tabular}

\subsection{Sub-group Meta-Analysis: Fatal and Non-Fatal Crash Injury}

Six studies measured crash outcomes as either fatal or non-fatal crash injuries. A total of 16 point estimates emerged from these six studies (Figure 3A). The rush-hour period was associated with a $32 \%$ increased risk of fatal and non-fatal crash injury (Pooled Risk Ratio: 1.32; 95\% CI: 1.18 - 1.46). The test for heterogeneity was considerably high across all selected studies since some studies had multiple entries $\left(I^{2}=89.59 \%\right)$. There was visual evidence of publication bias, with most of the selected studies asymmetrically located on one side the pooled effect size (Figure 3B). The Egger test was statistically significant $(\mathrm{p}<0.001)$, suggesting that there was statistical evidence of publication bias (Table 7). Using the Trim and Fill analysis, five studies were imputed ( $\mathrm{n}=21)$ (Figure 2C). The effect size, after adjusting for publication bias, was 1.31 (95\% CI: $1.17-1.45$ ), suggesting that the rush hour period was associated with $31 \%$ increased fatal and non-fatal crash injury (Table 7).

The subgroup analysis, measured by fatal and non-fatal crash injury status showed that the rush hour was associated with a $41 \%$ increased risk of fatal crash injury (Pooled Risk Ratio: 1.41; $95 \%$ CI: $1.35-1.48)$. There was moderate heterogeneity across the selected studies $\left(\mathrm{I}^{2}=\right.$ 44.65\%). The rush-hour period was associated with a $4 \%$ reduced risk of non-fatal crash injury, but the association was not statistically significant (Pooled Risk Ratio: 0.96; 95\% CI: 0.88 - 
medRxiv preprint doi: https://doi.org/10.1101/2021.08.03.21261572; this version posted August 5, 2021. The copyright holder for this preprint (which was not certified by peer review) is the author/funder, who has granted medRxiv a license to display the preprint in perpetuity.

All rights reserved. No reuse allowed without permission.

1.03). There was excellent heterogeneity across the studies $\left(\mathrm{I}^{2}=0.01 \%\right)$. The funnel plot of the subgroup analysis (fatal and non-fatal crash injury) showed the asymmetric distribution of studies under the funnel plot providing visual evidence of publication bias (Figure 4). 
medRxiv preprint doi: https://doi.org/10.1101/2021.08.03.21261572; this version posted August 5, 2021. The copyright holder for this preprint (which was not certified by peer review) is the author/funder, who has granted medRxiv a license to display the preprint in perpetuity. All rights reserved. No reuse allowed without permission.

Huang et al.,(2019)

Kim et al.,(2007)

Ma et al.,(2018)

Ma et al.,(2018)

Paleti et al.,(2010)

Stevens et al.,(2019)

Stevens et al.,(2019)

Stevens et al.,(2019)

Stevens et al.,(2019)

Stevens et al.,(2019)

Stevens et al.,(2019)

Stevens et al.,(2019)

Heterogeneity: $\mathrm{T}^{2}=0.00, \mathrm{I}^{2}=44.65 \%, \mathrm{H}^{2}=1.81$

Test of $\theta_{i}=\theta_{j}: Q(11)=30.38, p=0.00$

\section{Non-fatal}

Haleem et al.,(2013)

Haleem et al.,(2013)

Ma et al.,(2018)

Ma et al.,(2018)

Heterogeneity: $\mathrm{T}^{2}=0.00, \mathrm{I}^{2}=0.01 \%, \mathrm{H}^{2}=1.00$

Test of $\theta_{i}=\theta_{j}: Q(3)=6.61, p=0.09$

\section{Overall}

Heterogeneity: $\mathrm{T}^{2}=0.05, \mathrm{I}^{2}=89.59 \%, \mathrm{H}^{2}=9.61$

Test of $\theta_{i}=\theta_{j}: Q(15)=149.31, p=0.00$

Test of group differences: $Q_{b}(1)=84.87, p=0.00$ with $95 \% \mathrm{Cl}$

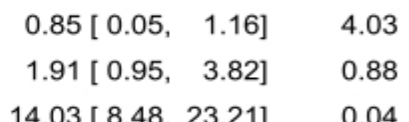

$7.03[2.05,24.07] \quad 0.02$

$1.48[0.99,2.20] \quad 3.60$

$1.49[1.38,1.62] \quad 10.06$

$1.48[1.34,1.61] \quad 9.87$

$1.60[1.44,1.75] \quad 9.59$

$1.40[1.35,1.50] \quad 10.53$

$1.35[1.24,1.44] \quad 10.29$

$1.35[1.20,1.41] \quad 10.24$

$1.32[1.18,1.40] \quad 10.18$

$1.41[1.35,1.48]$
$0.98[0.88,1.09] \quad 10.24$

$0.93[0.83,1.03] \quad 10.29$

$4.85[2.34,10.07] \quad 0.13$

$10.19[3.73,27.84] \quad 0.01$

$0.96[0.88,1.03]$

$1.32[1.18,1.46]$

Random-effects REML model
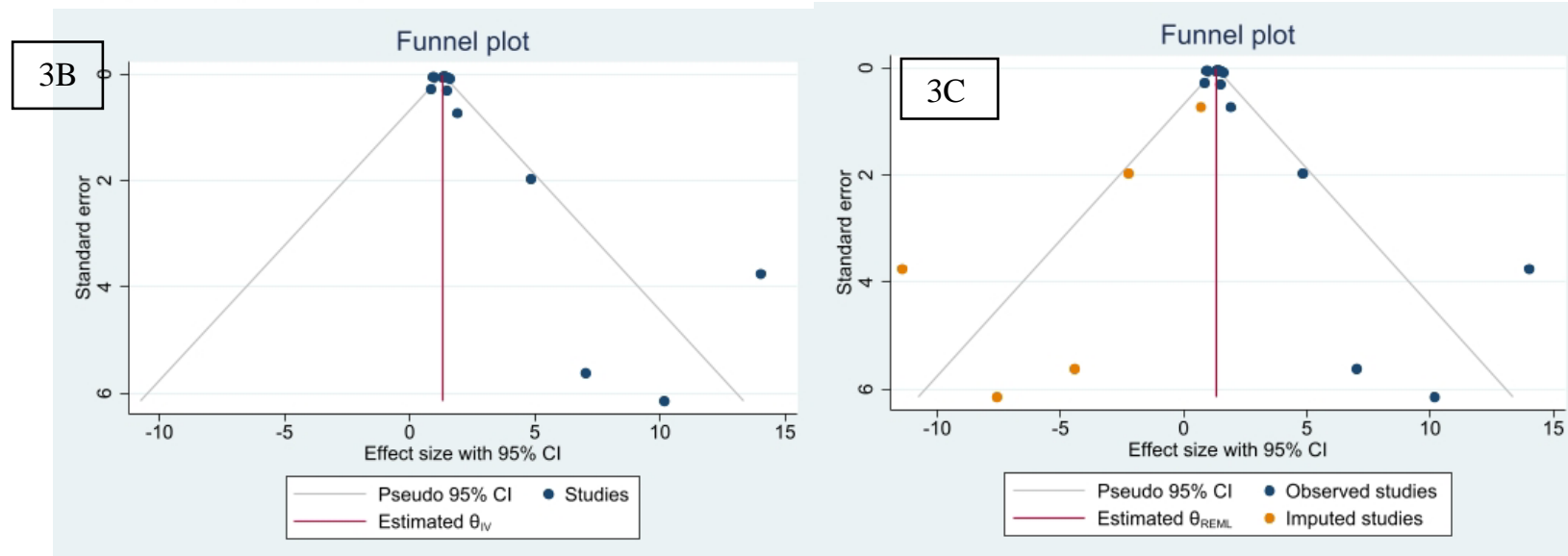

Figure 3: Forest plot (A) showing the sub-group analysis by fatal and non-fatal status, funnel plot (B) visualizing publication bias, and Trim and Fill analysis plot $(C)$ showing the adjustment for publication bias 
medRxiv preprint doi: https://doi.org/10.1101/2021.08.03.21261572; this version posted August 5, 2021. The copyright holder for this preprint (which was not certified by peer review) is the author/funder, who has granted medRxiv a license to display the preprint in perpetuity.

All rights reserved. No reuse allowed without permission.

Table 7: Summary of the Trim and Fill analysis of the sub-group analysis by fatal and non-fatal crash injury, showing the adjusted effect size and the Egger test evaluation of publication bias across the selected studies.

\begin{tabular}{lll}
\hline \multicolumn{2}{c}{ Trim and Fill Analysis } \\
\hline Studies & Theta & $95 \% \mathrm{Cl}$ \\
Observed $(\mathrm{n}=16)$ & 1.32 & $1.18-1.46$ \\
Observed + Imputed (21) & 1.31 & $1.17-1.45$ \\
& & \\
& & Regression-based Egger test for small-study effects \\
\hline Beta (Standard Error) & Z-value & 0.001 \\
$1.47(0.435)$ & 3.38 & \\
\hline
\end{tabular}

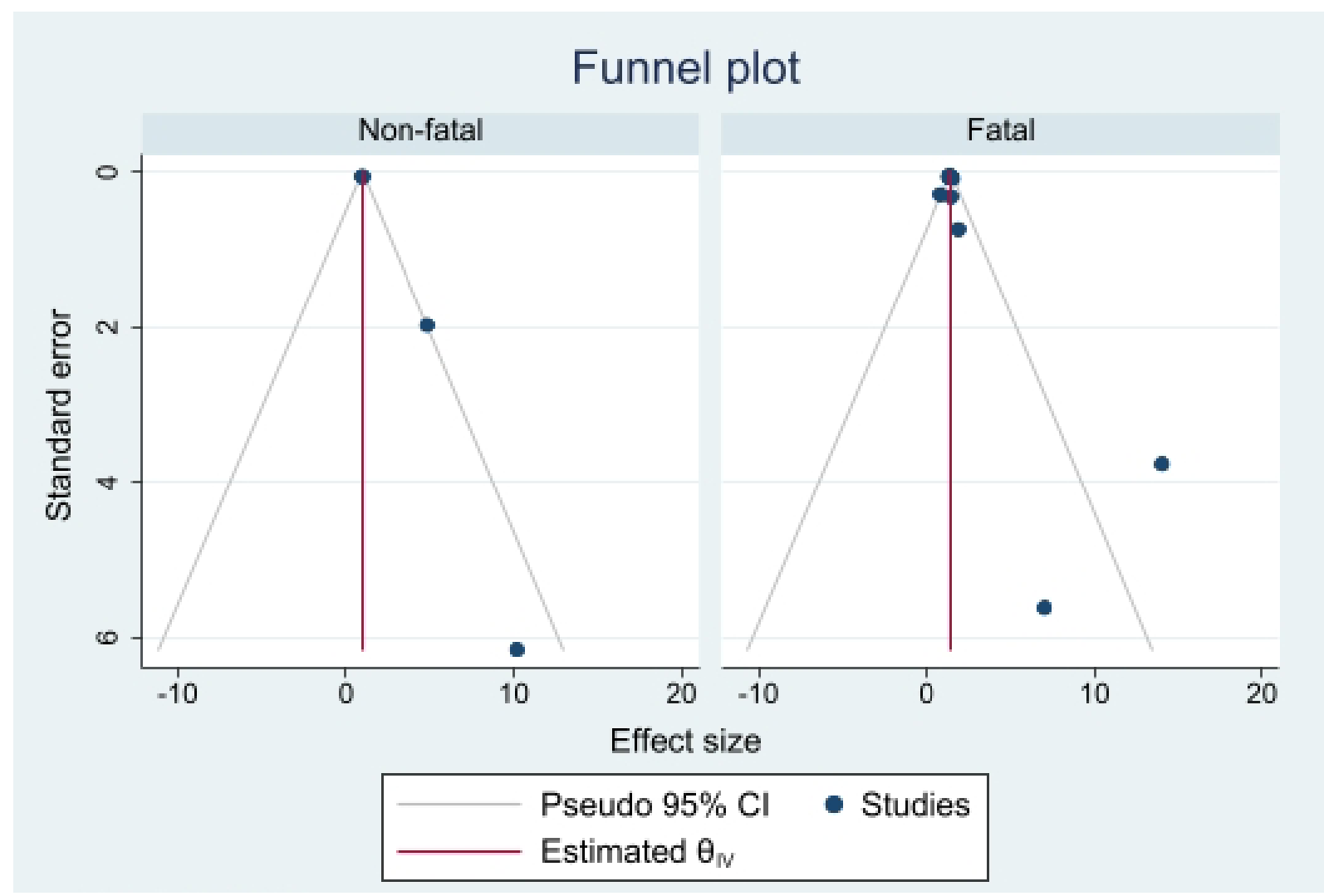

Figure 4: Funnel plot showing the distribution of studies in the subgroup analysis grouped by fatal and non-fatal crash injury 
medRxiv preprint doi: https://doi.org/10.1101/2021.08.03.21261572; this version posted August 5, 2021. The copyright holder for this preprint (which was not certified by peer review) is the author/funder, who has granted medRxiv a license to display the preprint in perpetuity.

All rights reserved. No reuse allowed without permission.

\subsection{Sub-group Meta-Analysis: Morning and Afternoon Rush Hour}

Four studies reported crash outcomes during the morning and afternoon rush hour periods. A total of 10 point estimates emerged from these four studies (Figure 5A). The rushhour period was associated with a $32 \%$ increased risk of fatal and non-fatal crash injury (Pooled Risk Ratio: $1.32 ; 95 \%$ CI: $1.18-1.47)$. The test for heterogeneity was considerably high across all selected studies $\left(\mathrm{I}^{2}=93.41 \%\right)$. Although most of the studies were symmetrically located around the pooled estimates, most of the studies were located outside of the margin of the funnel plot (Figure 5B). Since the margin of the funnel plot suggests where $95 \%$ of the studies would lie if there were no publication bias, the presence of some points outside of the margin made the visual interpretation of publication bias equivocal. The Egger test was not statistically significant $(\mathrm{p}=0.320)$, which suggests that there is no statistical evidence of publication bias. Using the Trim and Fill analysis, two studies were imputed $(n=12)$ (Figure 5C). The adjusted effect size was 1.29 (95\% CI: $1.14-1.43)$, suggesting that the rush hour period was associated with $29 \%$ increased fatal and non-fatal crash injury (Table 8).

The subgroup analysis, measured by morning and afternoon rush hour status showed that the morning rush hour period was associated with a $40 \%$ increased risk of fatal and non-fatal crash injury (Pooled Risk Ratio: 1.40; 95\% CI: 1.13 - 1.67). There was considerable high heterogeneity across the selected studies $\left(\mathrm{I}^{2}=92.85 \%\right)$. The afternoon rush hour period was associated with a 27\% increased risk of fatal and non-fatal crash injury (Pooled Risk Ratio: 1.27; $95 \%$ CI: $1.10-1.44)$. There was considerable high heterogeneity across the studies $\left(\mathrm{I}^{2}=\right.$ 93.44\%). The funnel plot of the subgroup analysis (morning and afternoon rush hour) showed the asymmetric distribution of studies under the funnel plot providing visual evidence of publication bias (Figure 6). 
medRxiv preprint doi: https://doi.org/10.1101/2021.08.03.21261572; this version posted August 5, 2021. The copyright holder for this preprint (which was not certified by peer review) is the author/funder, who has granted medRxiv a license to display the preprint in perpetuity. All rights reserved. No reuse allowed without permission.

5A Study

Effect size with $95 \% \mathrm{Cl}$ Weight

\section{AM}

Haleem et al.,(2013)

with $95 \% \mathrm{Cl}$

Kim et al.,(2007)

Stevens et al.,(2019)

Stevens et al.,(2019)

$0.98[0.88,1.09]$

11.11

Stevens et al.,(2019)

Heterogeneity: $\mathrm{T}^{2}=0.07, \mathrm{I}^{2}=92.85 \%, \mathrm{H}^{2}=13.98$

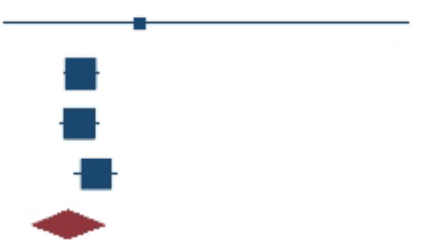

$1.91[0.95,3.82]$

0.95

$1.49[1.38,1.62]$

10.92

$1.48[1.34,1.61]$

10.71

Test of $\theta_{i}=\theta_{j}: Q(4)=66.53, p=0.00$

$1.60[1.44,1.75]$

10.40

\section{PM}

Haleem et al.,(2013)

Stevens et al.,(2019)

Stevens et al.,(2019)

Stevens et al.,(2019)

Stevens et al.,(2019)

Heterogeneity: $\mathrm{T}^{2}=0.03, \mathrm{I}^{2}=93.44 \%, \mathrm{H}^{2}=15.26$

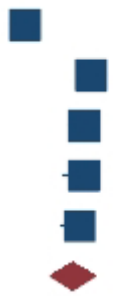

$0.93[0.83,1.03]$

11.17

Test of $\theta_{i}=\theta_{j}: Q(4)=60.93, p=0.00$

\section{Overall}

Heterogeneity: $\mathrm{T}^{2}=0.05, \mathrm{I}^{2}=93.41 \%, \mathrm{H}^{2}=15.17$

Test of $\theta_{i}=\theta_{j}: Q(9)=128.60, p=0.00$

Test of group differences: $Q_{b}(1)=0.65, p=0.42$

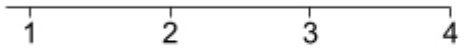

Random-effects REML model
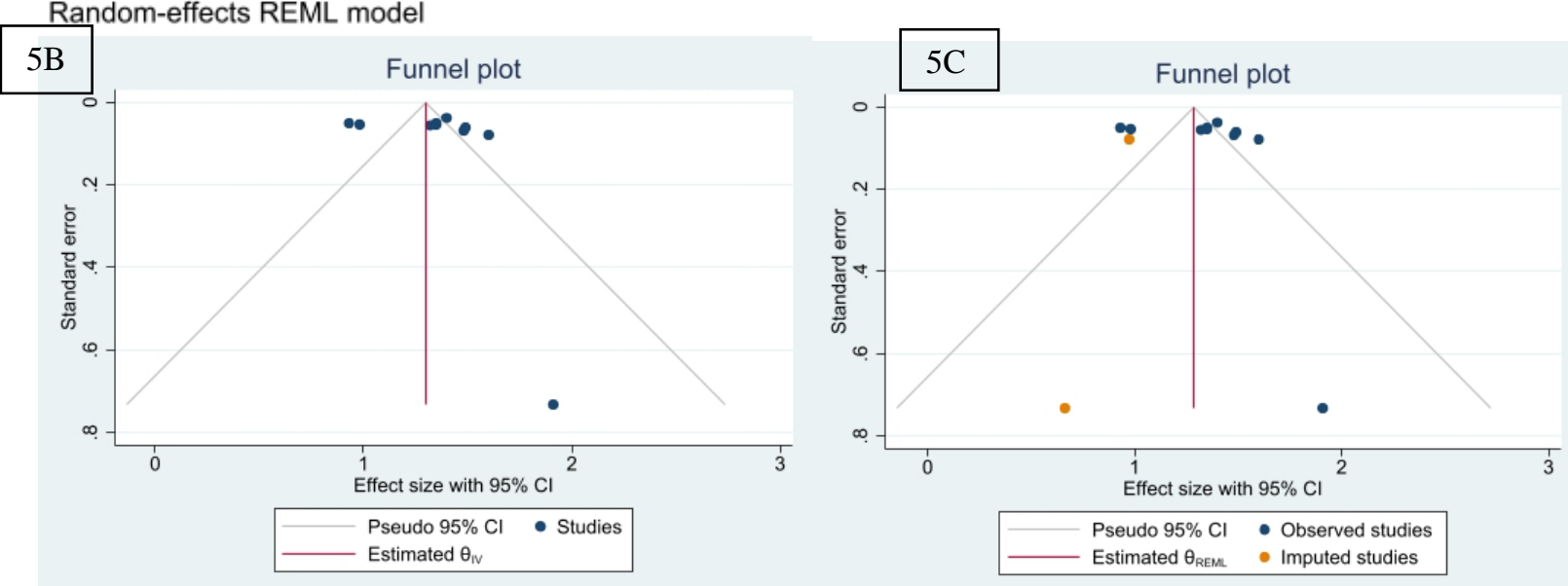

Figure 5: Forest plot (A) showing the sub-group analysis by morning and afternoon rush hour periods, funnel plot (B) visualizing publication bias, and Trim and Fill analysis plot (C) showing the adjustment for publication bias 
medRxiv preprint doi: https://doi.org/10.1101/2021.08.03.21261572; this version posted August 5, 2021. The copyright holder for this preprint (which was not certified by peer review) is the author/funder, who has granted medRxiv a license to display the preprint in perpetuity.

All rights reserved. No reuse allowed without permission.

Table 8: Summary of the Trim and Fill analysis of the sub-group analysis morning and afternoon rush hour period, showing the adjusted effect size and the Egger test evaluation of publication bias across the selected studies.

\begin{tabular}{lll}
\hline & \multicolumn{2}{c}{ Trim and Fill Analysis } \\
\hline Studies & Theta & $95 \% \mathrm{Cl}$ \\
Observed $(\mathrm{n}=10)$ & 1.32 & $1.18-1.47$ \\
Observed + Imputed (12) & 1.29 & $1.14-1.43$ \\
& & \\
& \multicolumn{2}{l}{ Regression-based Egger test for small-study effects } \\
\hline Beta (Standard Error) & Z-value & p-value \\
1.11 (1.12) & 0.99 & 0.320 \\
\hline
\end{tabular}

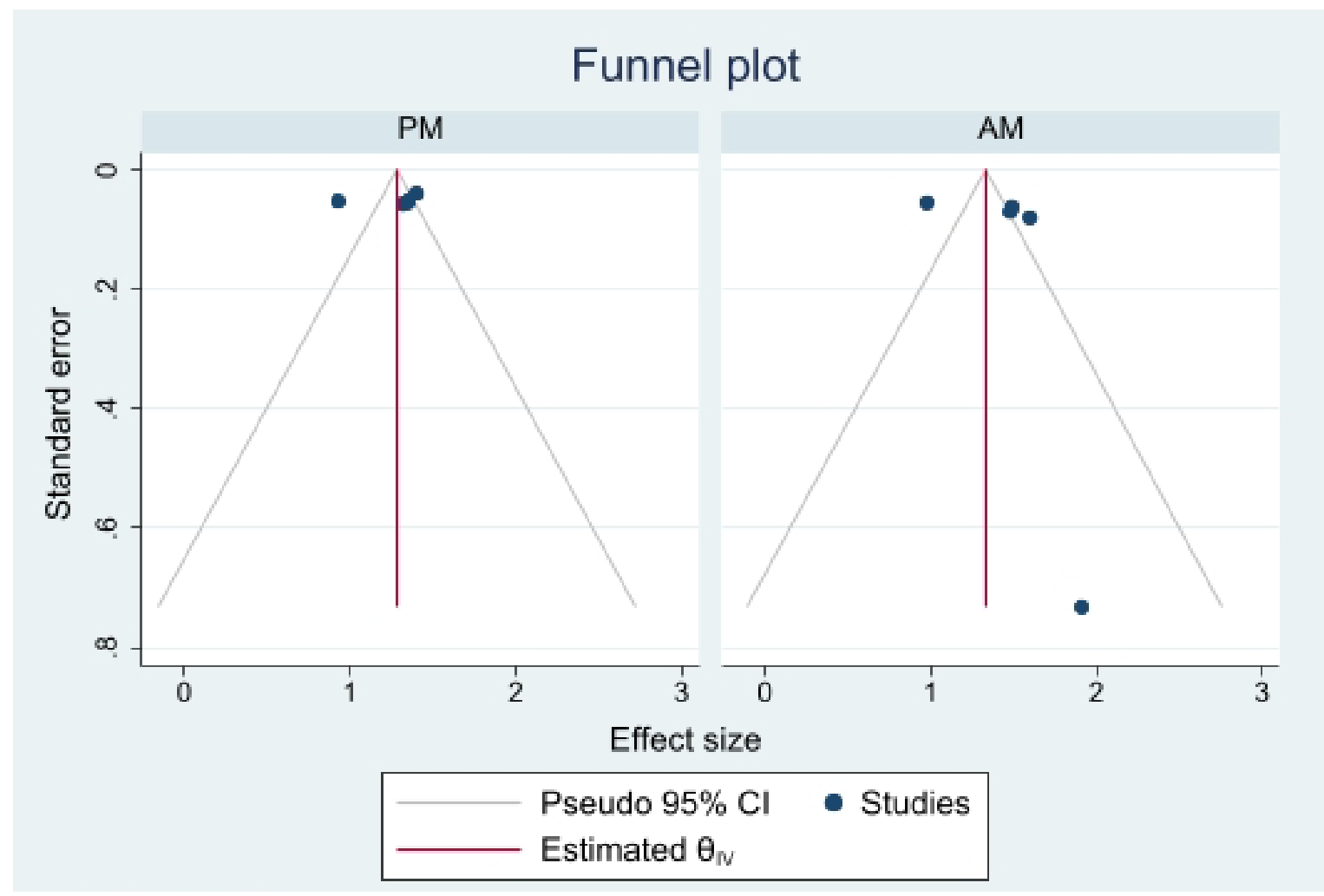

Figure 6: Funnel plot showing the distribution of studies in the subgroup analysis grouped by fatal and non-fatal crash injury 
medRxiv preprint doi: https://doi.org/10.1101/2021.08.03.21261572; this version posted August 5, 2021. The copyright holder for this preprint (which was not certified by peer review) is the author/funder, who has granted medRxiv a license to display the preprint in perpetuity.

All rights reserved. No reuse allowed without permission.

\subsection{Meta-Regression Analysis}

A meta-regression analysis assessed the relative risk of fatal and non-fatal crash injury by the morning and afternoon rush hour periods (Table 9). Compared to the afternoon rush hour period, the morning rush hour period was significantly associated with a $13 \%$ increased risk of fatal and non-fatal crash events (Pooled Risk Ratio: 1.13; 95\% CI: $1.05-1.22$ ).

Table 9: Summary of the meta-regression analysis using the rush hour categorization as the predictor.

\begin{tabular}{lll}
\hline \multicolumn{3}{c}{ Meta-Regression Analysis } \\
\hline Variable & RR $(95 \% \mathrm{Cl})$ & Coefficient $(95 \% \mathrm{Cl})$ \\
\hline Time & & \\
AM & $1.13(1.05-1.22)$ & $0.12(0.05-0.20)$ \\
PM & Ref & Ref \\
\hline
\end{tabular}


medRxiv preprint doi: https://doi.org/10.1101/2021.08.03.21261572; this version posted August 5, 2021. The copyright holder for this preprint

(which was not certified by peer review) is the author/funder, who has granted medRxiv a license to display the preprint in perpetuity.

All rights reserved. No reuse allowed without permission.

\section{Discussion}

Across the U.S., this study estimated that the median rush hour period was from 6 to 9 am and 3 to $7 \mathrm{pm}$ but the exact duration varies across states, population, population density, and county characteristics. A substantial proportion of crash events occurred during the rush hour period and rush hour traffic volume was associated with crash occurrences. Individual determinants (e.g., aggressive driving), vehicle determinants (e.g., truck driving, bicycle riding), and environmental determinants (e.g., precipitation) were associated with increased crash events or crash injuries. This study reports that the rush hour period was associated with an increased risk of fatal crash injury. The morning rush hour period was associated with increased crash injury risk compared to the afternoon rush hour period.

The rush-hour period signifies the period of "peak traffic flow" and in the U.S., two peak periods exist - the morning and afternoon rush-hour periods. Peak traffic densities vary across states, rural-urban status, county population and landmass, traffic zone regions, and time of the year. While this study identified wide-ranging rush hour periods, county-level duration in nonmetropolitan and rural counties may be shorter. An earlier report from the Federal Highway Administration estimated that peak traffic flow in cities with 500,000 to one million population lasts about six hours while cities with more than one million population may have peak traffic flow lasting approximately 7.5 hours (Federal Highway Administration, 2017).

While defining the rush hour period using discrete-time points has its advantages, the rush hour period is not static. Defining rush hour as a predictor of crash events may require quantifying the volume of traffic flow during the rush hour period, assessing the presence (or absence) of the variable of interest in the rush hour period, or using the rush hour period as an effect modifier, stratification, or interaction variable, if statistical criteria are met. Introducing 
indices of the rush hour period into analytical models may inform decisions on the appropriateness of using the rush hour period as a proxy for intervention. Additionally, understanding how the rush hour period associates with predictors of crash events or crash injury may inform policy on driving behavior, road environmental designs, and designs of safer vehicles, including self-driving cars.

While there exist significant fatal crash injuries during the morning and afternoon rush hour periods, the causes of such crash injuries may differ. The morning rush hour period represents the time most road users are rushing to their workplace. The afternoon rush hour period mirrors the period road users leave work to their homes or secondary destinations. Earlier studies have reported increased texting during the afternoon rush hour period compared to other times of the day (Drivemode Research Lab, 2018). While speeding may or may not be associated with the rush hour period depending on the type of road and the volume of vehicles, drivers are more likely to speed during the morning rush hour period than at any other time of the day (Richard et al., 2012). This driving behavior may explain the increased proportion of weatherrelated crashes during the morning rush hour period compared to the afternoon rush hour period (Call et al., 2019).

A few studies reported non-significant relationships between rush hour traffic volume and crash event/injury (Das et al., 2008; Haleem \& Gan, 2013; Lee et al., 2007). Conceptually, during the rush hour period, there should be reduced speed due to the increased density of vehicles on the road. However, this assumption may hold if the road type is either arterial roads or freeways. An earlier report by the Federal Highway Administration reported that crash fatality rates, measured at all times of the day, were highest on collectors and local streets and least on interstate and arterials (Federal Highway Administration, 2000). Studies selected in this review 
medRxiv preprint doi: https://doi.org/10.1101/2021.08.03.21261572; this version posted August 5, 2021. The copyright holder for this preprint (which was not certified by peer review) is the author/funder, who has granted medRxiv a license to display the preprint in perpetuity.

All rights reserved. No reuse allowed without permission.

that assessed crashes on arterial roads and freeways produced either reduced risks of crash events/injuries or non-statistical associations (Das et al., 2008; Haleem \& Gan, 2013; Lee et al., 2007). This may suggest that rush hour-related crash injuries may be less of a problem on roads with heavy traffic such as arterial roads and freeways and may be related to local streets and collectors.

Rush hour-related crashes are an under-researched area in traffic injury prevention. Thirteen papers assessed the relationship of rush hour, measured in any form, and crash injury or event. Eight of the 13 papers assessed the rush hour as a control variable, while the other studies used the rush hour period as a stratification or interaction variable or for descriptive purposes. Seven of the 13 papers were published within the last decade. None of the studies assessed the rush hour period or rush hour traffic volume as the main predictor of crash event/injury. While a few studies assessed the individual, vehicle, and environmental determinants of crash injury during the rush hour, research in the domains aimed at achieving zero fatality (Ecola et al., 2018; Federal Highway Administration, 2020) such as speeding, distracted driving, seatbelt use, road environmental infrastructure, and crash response, are missing. Additionally, no study evaluated the role of the social determinants of health (Healthy People, 2020) in the occurrence of fatal and non-fatal crash injuries in the U.S. Further, none of the studies used spatial or spatiotemporal estimators - tools that may adjust for spatial and temporal autocorrelation and provide information of cluster location.

Crash event and crash injury represent two different concepts that are aimed at achieving a single goal - injury prevention. A crash event refers to the presence of solitary or multiple collisions with or without the presence of injury or loss of lives. Crash injury captures the occurrence of the collision and the presence or absence of fatal or non-fatal injury. Also, there 
medRxiv preprint doi: https://doi.org/10.1101/2021.08.03.21261572; this version posted August 5, 2021. The copyright holder for this preprint (which was not certified by peer review) is the author/funder, who has granted medRxiv a license to display the preprint in perpetuity.

All rights reserved. No reuse allowed without permission.

exists a hierarchical difference in the crash event and crash injury conceptualization. A crash event (count or occurrence) may be conceptualized at the community level while crash injury may be measured at the individual level. Aggregating either measures of crash outcome to provide county, zip code or state-level estimates may require defining appropriate standardization which may be population estimates (Marquis \& Wang, 2015) or traffic volume (Abdel-Aty, Pemmanaboina, \& Hsia, 2006; Lee et al., 2007; Mitra \& Washington, 2012). While the NHTSA reports counts and rates of fatal and non-fatal crash injuries (National Center for Statistics and Analysis, 2019b; National Highway Traffic Safety Administration, 2018, 2019), information on weighted or adjusted estimates of fatal and non-fatal crash injuries would provide additional information on how the crash rates vary by states, across years, and by specific predictors.

This study has several limitations. All the studies employed a retrospective study design, and the observed relationship of the rush hour and crash injury does not infer causation. This study reports statistical evidence of publication bias, which may be due to earlier studies attenuating the report of non-significant variables (Das et al., 2008; Duddu et al., 2019). Also, there is a possibility that some publications were systematically missed as these articles might not have been indexed in the databases that were searched. The inherent weakness of the primary studies is reflected in this meta-analysis as issues relating to analytical bias, coverage and sampling errors, and misclassification of the rush hour period in the original studies might influence this study's results. Despite these limitations, this study represents one of the few studies that highlight the crash injury risks associated with the rush hour period. Additionally, this study identifies the rush hour period as an area needing more scholarly research and a potential proxy for different crash injury interventions. 


\section{Conclusion}

In summary, a substantial proportion of crash injuries occur during the rush hour period in the U.S. The morning and afternoon rush hour periods are each associated with an increased risk of fatal crash injuries in the U.S. As the U.S journeys towards achieving zero fatal deaths, there is a need for more scholarly research on the rush hour-related crash injury pattern. The knowledge of the pattern of crash injuries, as it varies across states, rurality/urbanicity, and counties may inform policy and the design of interventions. This systematic review and metaanalysis further demonstrate the paucity of information on the individual, environmental, and community-level crash injury determinants during the rush hour period. Increased knowledge of the pattern of rush hour-related fatal and non-fatal crash injuries may inform policies related to rush hour driving, resource allocation, and targeted interventions. 


\section{References}

Abdel-Aty, M., Pemmanaboina, R., \& Hsia, L. (2006). Assessing Crash Occurrence on Urban Freeways by Applying a System of Interrelated Equations. Transportation Research Record: Journal of the Transportation Research Board(1953), pp 1-9. Retrieved from https://doi.org/10.3141/1953-01

Ball, K., Owsley, C., Stalvey, B., Roenker, D. L., Sloane, M. E., \& Graves, M. (1998). Driving avoidance and functional impairment in older drivers. Accident Analysis \& Prevention, 30(3), 313-322. doi:https://doi.org/10.1016/S0001-4575(97)00102-4

Borenstein, M., Hedges, L. V., Higgins, J. P., \& Rothstein, H. R. (2010). A basic introduction to fixed $\square$ effect and random $\square$ effects models for meta $\square$ analysis. Research synthesis methods, 1(2), 97-111.

Call, D. A., Medina, R. M., \& Black, A. W. (2019). Causes of Weather-Related Crashes in Salt Lake County, Utah. Professional Geographer, 71(2), 253-264. doi:10.1080/00330124.2018.1501713

Center for Disease Control and Prevention. (2016). Road Traffic Injuries and Deaths-A Global Problem. Retrieved from https://www.cdc.gov/features/globalroadsafety/index.html

Cook, L. J., Knight, S., \& Olson, L. M. (2005). Comparison of Aggressive and DUI Crashes. Journal of Safety Research, 36(5), pp 491-493. Retrieved from https://trid.trb.org/view/778336

Das, A., Pande, A., Abdel-Aty, M. A., \& Santos, J. B. (2008). Characteristics of Urban Arterial Crashes Relative to Proximity to Intersections and Injury Severity. Transportation Research Record: Journal of the Transportation Research Board(2083), pp 137-144. Retrieved from https://doi.org/10.3141/2083-16 
Downs, S. H., \& Black, N. (1998). The feasibility of creating a checklist for the assessment of the methodological quality both of randomised and non-randomised studies of health care interventions. Journal of Epidemiology \& Community Health, 52(6), 377-384. doi:10.1136/jech.52.6.377

Drivemode Research Lab. (2018). Data Report: U.S. Drivers Message More During Afternoon Rush Than Any Other Time Behind The Wheel. https://drivemode.com/2018/04/datareport-messaging-times/

Duddu, V. R., Kukkapalli, V. M., \& Pulugurtha, S. S. (2019). Crash risk factors associated with injury severity of teen drivers. IATSS Research, 43(1), pp 37-43. Retrieved from https://doi.org/10.1016/j.iatssr.2018.08.003

Ecola, L., Popper, S. W., Silberglitt, R., \& Fraade-Blanar, L. (2018). The Road to Zero: A Vision for Achieving Zero Roadway Deaths by 2050. https://www.rand.org/pubs/research_reports/RR2333.html.

Federal Highway Administration. (2017). Traffic Congestion and Reliability: Trends and Advanced Strategies for Congestion MItigation. https://ops.fhwa.dot.gov/congestion_report/chapter3.htm

Federal Highway Administration. (2020). Safety Culture and the Zero Deaths Vision. Safety. Retrieved from https://safety.fhwa.dot.gov/zerodeaths/

Federal Highway Administration. (2000). Road Function Classifications. Retrieved from https://safety.fhwa.dot.gov/speedmgt/data_facts/docs/rd_func_class_1_42.pdf

Haleem, K., \& Gan, A. (2013). Effect of driver's age and side of impact on crash severity along urban freeways: A mixed logit approach. Journal of Safety Research, 46, 67-76. doi:10.1016/j.jsr.2013.04.002 
Healthy People. (2020). Social determinants of health. Retrieved from

https://www.healthypeople.gov/2020/topics-objectives/topic/social-determinants-ofhealth

HG.org. (2020). Fatal Car Accident Statistics. Retrieved from https://www.hg.org/legalarticles/fatal-car-accident-statistics-29836

Higgins, J. P., Thompson, S. G., Deeks, J. J., \& Altman, D. G. (2003). Measuring inconsistency in meta-analyses. BMJ, 327(7414), 557-560. doi:10.1136/bmj.327.7414.557

Hooper, P., Jutai, J. W., Strong, G., \& Russell-Minda, E. (2008). Age-related macular degeneration and low-vision rehabilitation: a systematic review. Canadian Journal of Ophthalmology, 43(2), 180-187. doi:https://doi.org/10.3129/i08-001Get

Huang, Y. Y., Liu, C., \& Pressley, J. C. (2019). Restraint use and injury in forward and rearfacing infants and toddlers involved in a fatal motor vehicle crash on a U. S. Roadway. Inj Epidemiol, 6(Suppl 1), 28. doi:10.1186/s40621-019-0200-4

Injury Prevention Committee. (2017). Evidence-Based Strategies/Interventions Review for Distracted Driving. Retrieved from https://www.dshs.texas.gov/emstraumasystems/GETAC/PDF/IPPEDistracted_Driving.pdf

Jaffe, E. (2014). Far Beyond Rush Hour: The Incredible Rise of Off-Peak Public Transportation. CITYLAB. Retrieved from https://trid.trb.org/view/1291247

Jang, K., Chung, K., Ragland, D. R., Chan, C.-Y., \& Transportation Research, B. (2008). Comparison of Collisions on HOV Facilities with Limited and Continuous Access During Peak Hours. 
Kim, J.-K., Kim, S., Ulfarsson, G. F., \& Porrello, L. A. (2007). Bicyclist injury severities in bicycle-motor vehicle accidents. Accident Analysis and Prevention, 39(2), 238-251. doi:10.1016/j.aap.2006.07.002

Kingham, S., Sabel, C. E., \& Bartie, P. (2011). The impact of the 'school run' on road traffic accidents: A spatio-temporal analysis. Journal of Transport Geography, 19(4), 705-711. doi:10.1016/j.jtrangeo.2010.08.011

Lee, J.-T., Dittberner, R., \& Sripathi, H. (2007). Safety Impacts of Freeway Managed-Lane Strategy: Inside Lane for High-Occupancy Vehicle Use and Right Shoulder Lane as Travel Lane During Peak Periods. Transportation Research Record: Journal of the Transportation Research Board(2012), pp 113-120. Retrieved from https://doi.org/10.3141/2012-13

Lin, L., \& Chu, H. (2018). Quantifying publication bias in meta-analysis. Biometrics, 74(3), 785 794. doi:10.1111/biom. 12817

Llamazares, J., Useche, S. A., Montoro, L., \& Alonso, F. (2019). Commuting accidents of Spanish professional drivers: when occupational risk exceeds the workplace.

International Journal of Occupational Safety and Ergonomics, 1-9. doi:10.1080/10803548.2019.1619993

Ma, C., Hao, W., Xiang, W., \& Yan, W. (2018). The Impact of Aggressive Driving Behavior on Driver-Injury Severity at Highway-Rail Grade Crossings Accidents. Journal of Advanced Transportation, 2018(Article ID 9841498), 10p. Retrieved from https://doi.org/10.1155/2018/9841498

Marquis, R., \& Wang, X. (2015). Investigating Temporal Effects on Truck Accident Occurrences in Manhattan, New York City. Transportation Research Record: Journal of the 
medRxiv preprint doi: https://doi.org/10.1101/2021.08.03.21261572; this version posted August 5, 2021. The copyright holder for this preprint (which was not certified by peer review) is the author/funder, who has granted medRxiv a license to display the preprint in perpetuity.

All rights reserved. No reuse allowed without permission.

Transportation Research Board(2517), pp 10-17. Retrieved from

https://doi.org/10.3141/2517-02

Mitra, S., \& Washington, S. (2012). On the significance of omitted variables in intersection crash modeling. Accid Anal Prev, 49, 439-448. doi:10.1016/j.aap.2012.03.014

National Center for Statistics and Analysis. (2019a). 2018 Fatal Motor Vehicle Crashes:

Overview. Traffic Safety Fact: Research Note.

https://crashstats.nhtsa.dot.gov/Api/Public/ViewPublication/812826

National Center for Statistics and Analysis. (2019b). Summary of Motor Vehicle Crashes: 2017 data. Traffic Safety Facts Report.

https://crashstats.nhtsa.dot.gov/Api/Public/ViewPublication/812794

National Highway Traffic Safety Administration. (2017). 2017 Fatal Motor Vehicle Crashes:

Overview. https://crashstats.nhtsa.dot.gov/Api/Public/ViewPublication/812603

National Highway Traffic Safety Administration. (2018). Fatalities and Fatality Rates by

STATE, 1994 - 2018 - State : USA. Retrieved from https://www-

fars.nhtsa.dot.gov/States/StatesFatalitiesFatalityRates.aspx

National Highway Traffic Safety Administration. (2019). Crash Type/Crash Information. All

NCSA Publication Topics. Retrieved from

https://crashstats.nhtsa.dot.gov/\#/PublicationList/35

Paleti, R., Eluru, N., \& Bhat, C. R. (2010). Examining the influence of aggressive driving behavior on driver injury severity in traffic crashes. Accident Analysis \& Prevention, 42(6), 1839-1854. doi:10.1016/j.aap.2010.05.005

Peters, J. L., Sutton, A. J., Jones, D. R., Abrams, K. R., \& Rushton, L. (2008). Contour-enhanced meta-analysis funnel plots help distinguish publication bias from other causes of 
asymmetry. Journal of Clinical Epidemiology, 61(10), 991-996.

doi:10.1016/j.jclinepi.2007.11.010

Richard, C. M., Campbell, J. L., Lichty, M. G., Brown, J. L., Chrysler, S., Lee, J. D., .. . Reagle, G. (2012). Motivations for speeding, Volume I: Summary report. 1. https://www.nhtsa.gov/sites/nhtsa.dot.gov/files/811658.pdf

Schmidt, C. O., \& Kohlmann, T. (2008). When to use the odds ratio or the relative risk?

International journal of public health, 53(3), 165. Retrieved from https://link.springer.com/content/pdf/10.1007/s00038-008-7068-3.pdf

Shi, Q., Abdel-Aty, M., \& Lee, J. (2016). A Bayesian ridge regression analysis of congestion's impact on urban expressway safety. Accident Analysis \& Prevention, 88, 124-137. doi:https://doi.org/10.1016/j.aap.2015.12.001

Shi, L., \& Lin, L. (2019). The trim-and-fill method for publication bias: practical guidelines and recommendations based on a large database of meta-analyses. Medicine (Baltimore), 98(23), e15987. doi:10.1097/md.0000000000015987

StataCorp. (2020). Stata Statistical Software: Release 16. College Station, TX: StataCorp LLC.

Stevens, S. E., Schreck, C. J., Saha, S., Bell, J. E., \& Kunkel, K. E. (2019). Precipitation and Fatal Motor Vehicle Crashes: Continental Analysis with High-Resolution Radar Data. Bulletin of the American Meteorological Society, 100(8), 1453-1462. doi:10.1175/bamsd-18-0001.1

Sze, N.-N., \& Wong, S. (2007). Diagnostic analysis of the logistic model for pedestrian injury severity in traffic crashes. Accident Analysis and Prevention, 39(6), 1267-1278. doi:10.1016/j.aap.2006.07.002 
Tahir, M. N., Macassa, G., Akbar, A. H., Naseer, R., Zia, A., \& Khan, S. (2013). Road traffic crashes in Ramadan: an observational study. Eastern Mediterranean Health Journal, 19, S147-S151. https://apps.who.int/iris/handle/10665/118605

Tippett, R. (2014). 1 in 4 car accidents occur during rush hour. Retrieved from https://www.ncdemography.org/2014/03/24/1-in-4-car-accidents-occur-during-rush-hour/

Vorona, R. D., Szklo-Coxe, M., Wu, A., Dubik, M., Zhao, Y., \& Ware, J. C. (2011). Dissimilar teen crash rates in two neighboring southeastern Virginia cities with different high school start times. J Clin Sleep Med, 7(2), 145-151.

https://www.ncbi.nlm.nih.gov/pmc/articles/PMC3077341/pdf/jcsm.7.2.145.pdf

World Health Organization. (2015). Global status report on road safety 2015. Violence and Injury Prevention. Retrieved from https://www.who.int/violence_injury_prevention/road_safety_status/2015/en/

World Health Organization. (2019). Global status report on road safety 2018. In. Retrieved from https://www.who.int/violence_injury_prevention/road_safety_status/2018/en/

Yu, R., Wang, X., Yang, K., \& Abdel-Aty, M. (2016). Crash risk analysis for Shanghai urban expressways: A Bayesian semi-parametric modeling approach. Accident Analysis \& Prevention, 95, 495-502. doi:https://doi.org/10.1016/j.aap.2015.11.029

Zhang, G., Yau, K. K. W., Zhang, X., \& Li, Y. (2016). Traffic accidents involving fatigue driving and their extent of casualties. Accident Analysis \& Prevention, 87, 34-42. doi:10.1016/j.aap.2015.10.033

Zhang, W., Wang, K., Wang, L., Feng, Z., \& Du, Y. (2016). Exploring factors affecting pedestrians' red-light running behaviors at intersections in China. Accident Analysis \& Prevention, 96, 71-78. doi:https://doi.org/10.1016/j.aap.2016.07.038 